\title{
Pennsylvanian fossil flora from the Velebit Mountains and Lika region (SW Croatia)
}

\author{
Christopher J. Cleal, Yanaki G. Tenchov, Jasenka SRemac, TAMARA Đerek \\ \& SANJA JAPUNDŽIĆ
}

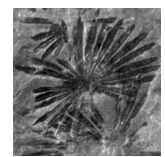

\begin{abstract}
Late Pennsylvanian age deposits in the Velebit Mts and Lika region of Croatia are mainly marine, but also include relative thin terrestrial intercalations yielding diverse fossil floras. A revision of the fossil floras, based on about 200 specimens in the collections of the Croatian Natural History Museum (Zagreb) and National Museum (Prague), has revealed 19 species, strongly dominated by medullosaleans, sphenophytes and marattialean ferns. These fossils represent the remains of the lowland vegetation that was growing on the southern side of the Variscan Mountains, and can be compared with similar floras found in northern Spain and the Carnic Alps. Similar aged floras also occurred in intramontane sequences further north and west in Europe but these often tend to be dominated by marattialean ferns and cordaitaleans rather than alethopterid medullosaleans as in the Croatian floras. These differences are probably the result of the higher elevation and better drainage of the intramontane basins. Biostratigraphically the Croatian floras belong to the S. angustifolium Zone of Stephanian B (late Kasimovian or earliest Gzhelian) age. - Key words: Pennsylvanian, palaeobotany, Croatia.
\end{abstract}

Cleal, C.J., Tenchov, Y.G., Sremac, J., ĐereK, T. \& JapundžIĆ, J. 2015. Pennsylvanian fossil flora from the Velebit Mountains and Lika region (SW Croatia). Bulletin of Geosciences 90(3), 721-742 (8 figures, 2 tables). Czech Geological Survey, Prague. ISSN 1214-1119. Manuscript received August 12, 2014; accepted in revised form July 9, 2015; published online September 30, 2015; issued September 30, 2015.

Christopher J. Cleal (corresponding author), Department of Natural Sciences, National Museum Wales, Cathays Park, CardiffCF 10 3NP, UK; chris.cleal@ museum wales.ac.uk •Yanaki G. Tenchov, Geological Institute of the Bulgarian Academy of Sciences, G. Bonchev Street Block 24, 1113 Sofia, Bulgaria $\bullet$ Jasenka Sremac, Institute of Geology and Palaeontology, Department of Geology, Faculty of Science, University of Zagreb, Horvatovac 102a, 10000 Zagreb, Croatia • Tamara Đerek \& Sanja Japundžić, Croatian Natural History Museum, Demetrova 1, 10000 Zagreb, Croatia

Most Carboniferous strata in Croatia are of marine origin and contain few remains of terrestrial plants (Sremac 2012). The most notable exceptions are found in terrestrial intercalations within the mainly marine sequence in the Velebit Mts and Lika region in the western part of the country (Fig. 1). These were first reported by Němejc (1936) and many of the specimens he described are now stored in the National Museum (Prague). Further plant fossils were collected by M. Salopek and his team during the 1935-1938 geological mapping of this area (Salopek 1942, 1948) and these are in the Croatian Natural History Museum (Zagreb). Most recently, staff of the Croatian Natural History Museum have found a new locality with terrestrial plants, at Strmotić potok creek.

Němejc (1936) suggested that these plant fossils are of Stephanian (Late Pennsylvanian) age and so represent some of the palaeotropical vegetation that developed during the major interglacial of the Late Palaeozoic Ice Age (Gastaldo et al. 1996; Cleal \& Thomas 1999, 2005). As with the better known fossil floras of this age found in northern Spain (summarised by Wagner \& Alvarez-Vázquez 2010a) these Croatian fossil floras represent vegetation growing on the southern side of the Variscan Mountains. This is in contrast to some of the other classic floras of this age found in France, Germany and the Czech Republic (e.g. Doubinger 1956, Remy et al. 1963, Vetter 1968, Šimůnek in Pešek 1994, Doubinger et al. 1995, Šimůnek \& Martínek 2009), which occur in intramontane basins formed within the Variscan Orogen. As there has been no taxonomic study on these Croatian floras other than that of Němejc (1936), a revision is clearly overdue. The present study combines data from both the Němejc (1936) collection in Prague, and the more recently collected material in Zagreb, to provide the most comprehensive taxonomic overview of these floras to date. The biostratigraphical and floristic context of the floras will also be re-examined, with the aim of improving our understanding of the vegetation history of southeastern Europe during the Late Pennsylvanian interglacial. 


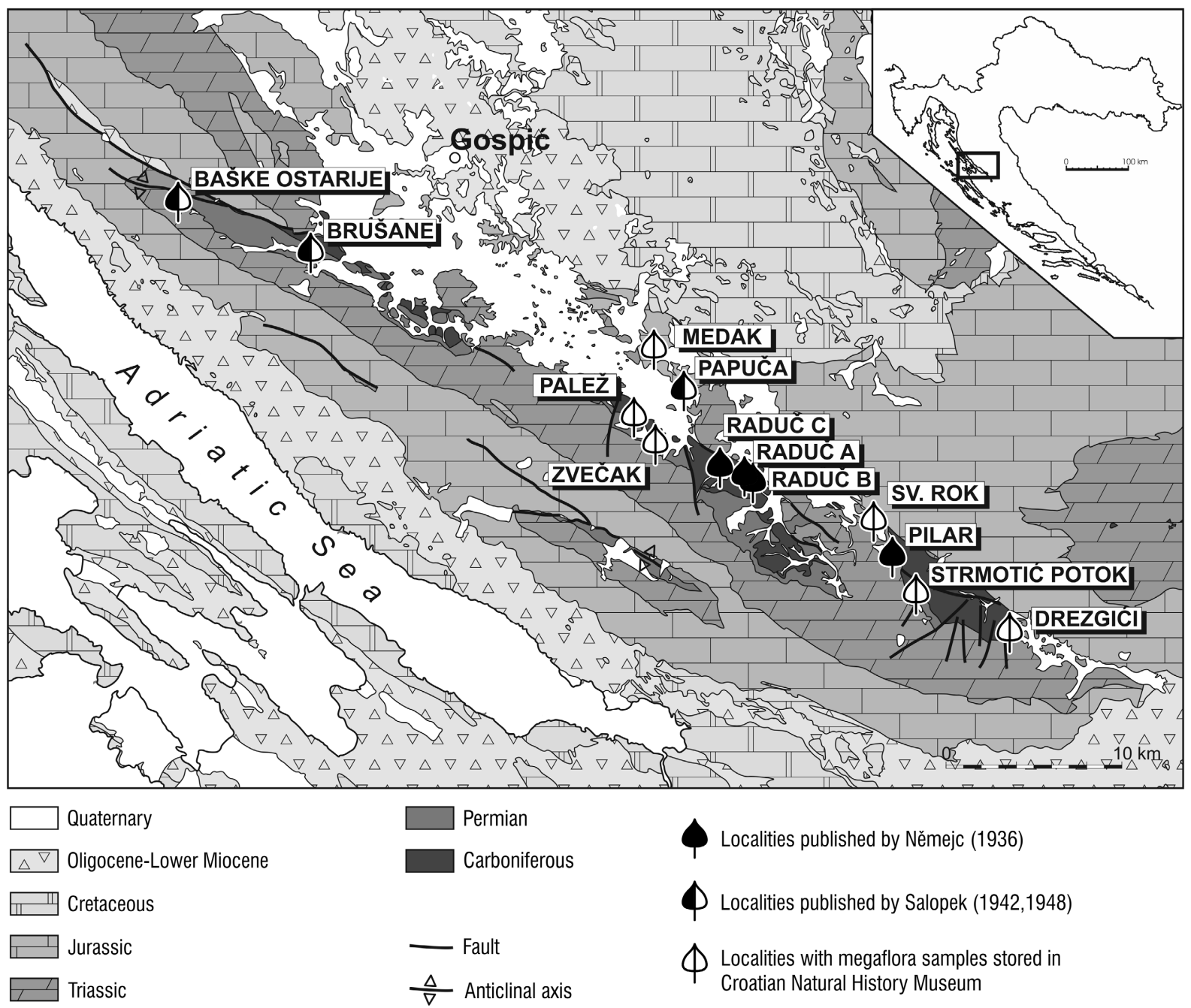

Figure 1. Simplified geological map with megaflora bearing localities (map based upon Ivanović et al. 1973; Šušnjar et al. 1973; Sokač et al. 1976b, c).

\section{Geological background}

The first detailed analysis of the geology of the Velebit Mts and Lika region was by $\mathrm{M}$. Salopek and his team during the 1935-1938 mapping of the area (Salopek 1942, 1948). Subsequent more detailed mapping, for the purpose of the Basic Geological Map of Yugoslavia, took place in the second half of the $20^{\text {th }}$ century; Carboniferous deposits are shown on sheets Gospić L33-127 (Sokač et al. 1974, 1976a), Obrovac L33-140 (Ivanović et al. 1973, 1976) and Udbina L33-128 (Šušnjar et al. 1973, Sokač et al. 1976b). The last cycle of mapping for the Basic Geological Map of Croatia, which included the research area, resulted in a 1:300,000 map with explanatory notes edited by Velić \& Vlahović (2009).

Clastic and carbonate rocks of Pennsylvanian age crop out in a ca $50 \mathrm{~km}$ long belt in this region, representing the core of the Velebit Anticline (Fig. 1). Marine shelf limestones dominate in the lower and upper parts of the succes- sion, and these contain calcareous algae, fusulinids, molluscs, trilobites, brachiopods and crinoids (Fig. 2). A Moscovian to Gzhelian age for these deposits is indicated by microfossils (Kochansky-Devidé 1955, 1970).

Terrestrial plant fossils occur in the middle part of the succession, in deposits that are lithologically and faunally similar to the Auernig or Pramollo Group of Kasimovian-Gzhelian age (= Rauserites Zone sensu Merino-Tomé et al. 2009), present in the Austrian, Slovenian and Italian Alps (Fritz \& Krainer 2006, 2007; Ronchi et al. 2012). Quartz-rich conglomerates, cross-bedded sandstones and graywackes, and bioturbated fossiliferous shales and sandstones are common in the lower part of the group. The upper part is characterized by evident transgressive-regressive cycles caused by Gondwana glaciation, known as "Auernig cyclothems" (McCann et al. 2008 and references therein). Limestone intercalations containing marine fossils were deposited during sea-level highstands, while siliciclastic deposits with sporadic occurrences of terres- 
Christopher J. Cleal et al. • Pennsylvanian fossil flora from SW Croatia

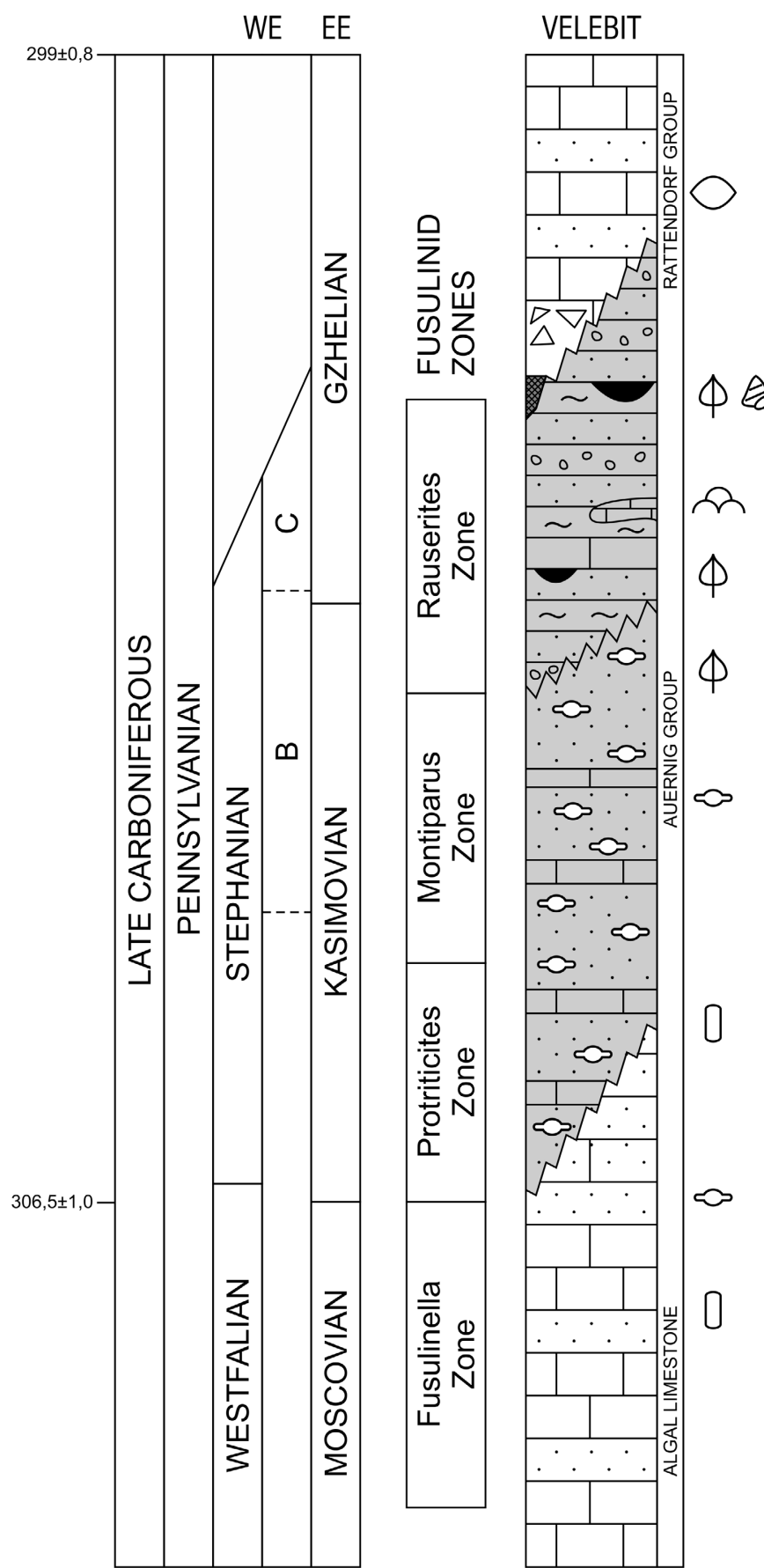

trial plant remains represent periods of sea-level lowstands. More detailed description of these rocks, with a list of older references is given by Sremac (2012).

\section{Materials and methods}

This study was based on about 200 specimens, mostly leaves, with some stems and reproductive structures. Of these, 151 are in collections in Zagreb, either at the Croatian Natural
Figure 2. Schematic geological column through the Pennsylvanian deposits of the Velebit Mts (based upon KochanskyPseudoschwagerina cf. alpina Devidé 1955, 1970; MerinoTomé et al. 2009; Sremac 2012). WE = Western Europe; $\mathrm{EE}=$ Eastern Europe.

Rugosofusulina complicata

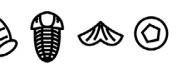

Anthracoporella spectabilis

Anthracoporella viana

"Triticites" brevispira Eoparafusulina pusilla Eoparafusulina pseudosimplex

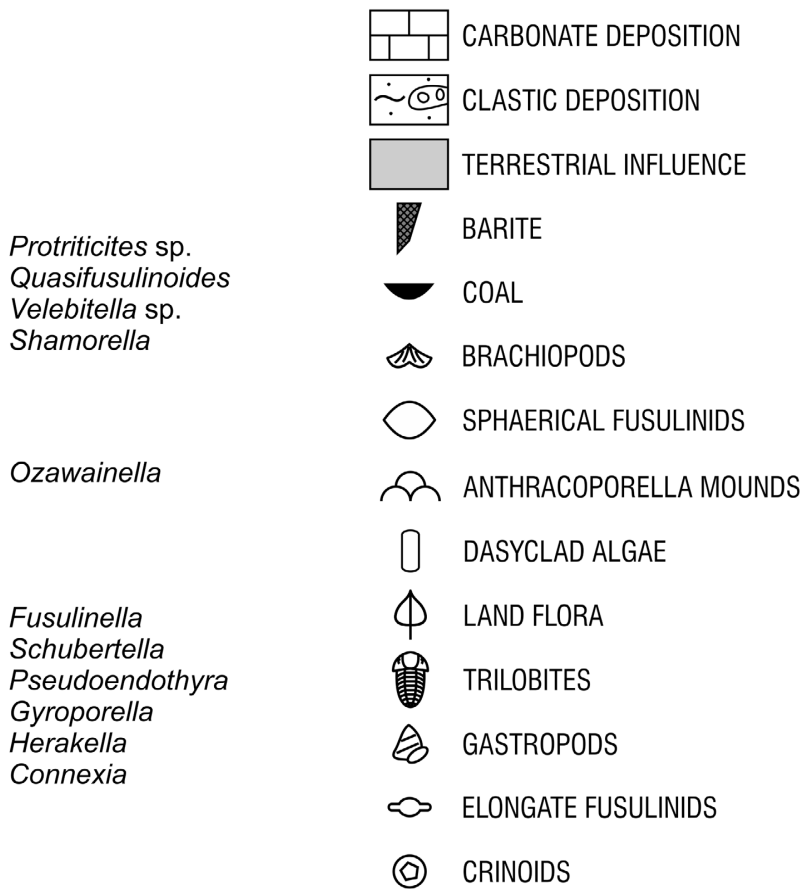

History Museum or the University of Zagreb (GPZ). These include remains from nine localities, collected since 1935, including the newly discovered Strmotić potok Creek locality (Table 1). There are also 47 specimens in the collections of the National Museum (Prague) under accession number 24860, which comprise part of the material described by Němejc (1936).

All specimens are either impressions or poorly preserved compressions, and yield no cuticles or provide any other anatomical evidence. The descriptions are, therefore, 
Table 1. Distribution of the species in the Velebit Mts fossil flora.

\begin{tabular}{|c|c|c|c|c|c|c|c|c|c|}
\hline & Brušane & Drezgići & Medak & Oštarije & Palež W. & Papuča & Strmotić & Sv. Rok & Zvečak \\
\hline ?Lepidodendron sp. & & & & + & & & + & & \\
\hline Annularia spinulosa & & & & & & & + & & \\
\hline Asterophyllites equisetiformis & + & & & & & & & & \\
\hline Calamites suckowii & & & & & & & + & & \\
\hline Acitheca polymorpha & & & + & & & & $?$ & & \\
\hline Lobatopteris cf. corsinii & & & & & & & + & & \\
\hline ?Cyathocarpus spp. & & + & & & & & + & & \\
\hline Oligocarpia gutbieri & & & & & & & & & + \\
\hline Fern fragment & & & & & & & & + & \\
\hline Eusphenopteris rotundiloba & & & & & & & + & & \\
\hline Dicksonites plukenetii & & & & & & & + & & \\
\hline Alethopteris zeilleri & & & & & & & + & & \\
\hline Alethopteris pennsylvanica & + & & & & & & & & \\
\hline Trigonocarpus aff. grandis & & & & & & & + & & \\
\hline Trigonocarpus sp. & & & & & & & + & & \\
\hline Neuropteris sp. & & + & & & + & & & & \\
\hline Odontopteris schlotheimii & + & & & & & & & & \\
\hline Callipteridium pteridium & & & & & & & + & & \\
\hline Taeniopteris carnotii & & & & & & & + & & \\
\hline
\end{tabular}

based purely on the morphology of the plant remains. The fossils were photographed in the Croatian Natural History Museum by R. Drempetić using high resolution cameras: Canon EOS 350 D (photo: N. Borčić) and Olympus SP-570 UZ.

\section{Systematic palaeontology}

Class Lycopsida Scott, 1909

Order Lepidocarpales Thomas \& Brack-Hane, 1984

Family uncertain

\section{Genus Lepidodendron Sternberg, 1820}

\section{?Lepidodendron $\mathrm{sp}$.}

Figure $3 \mathrm{~A}-\mathrm{C}$

(?)1936 Lepidodendron sp.; Němejc, p. 11, fig. 3.

(?)1936 Lepidostrobus geinitzi Zeiller; Němejc, p. 12, fig. 4.

Material. - Eight specimens of bark, leafy shoot and cone (specimens 12, STR1, STR2, STR8, STR18; plus three unnumbered). Also another possible stem and two cones in the Němejc Collection in the National Museum (Prague).

Description. - Three examples of stem/bark with large, helically arranged, rhomboidal leaf cushions $25 \mathrm{~mm}$ long, $15 \mathrm{~mm}$ wide, with rounded lateral angles (Fig. 3A). Cus- hions do not protrude significantly from stem surface, and separated by a $2 \mathrm{~mm}$ wide inter-cushion area. Small, isodiametric leaf scar in middle of each cushion, $c a 2 \mathrm{~mm}$ in size, with marked lateral lines extending from scar to lateral angles of cushion; in some cases a weakly developed keel also extends from the scar up to the apical angle of the cushion. A (?) ligule mark occurs ca $2 \mathrm{~mm}$ above scar. No other structure or ornamentation visible on scars.

Associated with the barks are slender shoots, preserved for up to $90 \mathrm{~mm}$ bearing slender leaves, 10-12 $\mathrm{mm}$ long and $<0.5 \mathrm{~mm}$ wide (Fig. 3B). The leaves were helically attached (as shown by the small leaf scars visible on the facing side of the stem) at about right angles to the stem. There are also occasional long, linear leaves, at least $140 \mathrm{~mm}$ long and $3 \mathrm{~mm}$ wide, with what appear to be a single longitudinal vein, which may represent Cyperites-like stem leaves of this lycopsid.

Also present are incomplete fragments of large cones (Fig. 3C), preserved for a length of up to $80 \mathrm{~mm}$, and originally about $30 \mathrm{~mm}$ wide (based on the distance between the cone axis and the distal ends of the sporophylls). Cone axis $2 \mathrm{~mm}$ wide. Sporophylls helically attached at $60-80^{\circ}$ (this variation may be partly taphonomic), extend for about $13 \mathrm{~mm}$ from the axis, where they bend sharply towards the distal end of the cone, forming the distal blade of the sporophyll. Details of the sporangia are difficult to see but some look as though they have megaspores. The sporophyll blade is up to $30 \mathrm{~mm}$ long, 2-3 mm wide, with an acute apex, and seems to extend away from the main body of the cone. 
Remarks. - The identity of these unusual fossils is unclear. Despite an extensive review of the literature, we have been unable to find any comparable species with such distinctive large, rhomboidal leaf cushions. It is assumed that they are lycopsid and the presence of a possible ligule just above the leaf scars suggests they probably represent Lepidodendron bark. There is some similarity with Lepidodendron feistmantelii Zalessky, 1904 (as documented by Thomas 1970) but the type of that species is rather older (Moscovian), and the leaf cushions are smaller and more protuberant from the stem surface. There is also some comparison with the specimen figured by Wagner \& Alvarez-Vázquez (2010a, pl. 25, fig. 1) as "Lepidodendron" gaudryi Renault \& Zeiller, 1888 but the upper and lower angles of the leaf cushions are rather sinuous, a feature not seen in the Velebit Mts specimens. A third comparison is possible with "Lepidodendron" clipeiforme Vetter (Doubinger et al. 1995, figs 17-19), which has similarly large leaf cushions but lacking the lateral lines seen in the Velebit Mts specimen. The type of Vetter's species appears to show persistent leaves and so should not be regarded as a Lepidodendron as interpreted by Thomas \& Meyen (1984). Until better material is uncovered, the Velebit Mts specimens are best referred to simply as (?)Lepidodendron sp.

Němejc (1936) figured a specimen of a Lepidodendron stem in which the leaf cushions are of similar shape, but of more oval outline. This might be the same as the species documented in the present paper, but the poor preservation makes it impossible to be sure. Němejc (1936) also figured a cone that is very similar to, but less well preserved than the cones documented here.

Class Equisetopsida Agardh, 1825

Order Equisetales Dumortier, 1829

Family Calamostachyaceae Meyen, 1978

\section{Genus Annularia Sternberg, 1821}

\section{Annularia spinulosa Sternberg, 1821}

Figure 3E

1804 Schlotheim, pl. 1, fig. 4.

1820 Casuarinites stellatus Schlotheim. - Schlotheim, p. 397 (nom. illegit.).

1821 Annularia spinulosa Sternberg, p. 32, pl. 19, fig. 4.

1825 Bornia stellata Schlotheim ex Sternberg, tent. p. 28.

1936 Annularia stellata Schlotheim. - Němejc, p. 10, pl. 2, figs 6-8.

2000 Annularia spinulosa Sternberg. - Barthel, p. 37, figs 1-5.

2004 Annularia spinulosa Sternberg. - Barthel, p. 20, figs 17,18 .
Material. - Seventeen specimens of leafy shoot (specimens $1,2,15$, plus 14 unnumbered). Also one specimen in the Němejc Collection in the National Museum (Prague).

Description. - Leafy shoots preserved for up to $110 \mathrm{~mm}$ long, with whorls of slender leaves spaced at $22 \mathrm{~mm}$ in more distal parts of the shoot, reducing to $10 \mathrm{~mm}$ in shoot apex. Few whorls are complete, but mostly seem to have ca 20-30 leaves. Leaves 12-25 mm long, $<2 \mathrm{~mm}$ wide. In some whorls the leaves are of equal length, in others the lateral whorls (as preserved on the rock) are rather longer. Leaves lanceolate, widest in the middle or somewhat more distal part, and terminated in a narrowly rounded apex. Leaves of a whorl basally but narrowly fused. A single thick vein runs along entire length of leaf.

Remarks. - Historically this species has tended to be named Annularia stellata (Schlotheim ex Sternberg) Wood, but Barthel (2000, 2004) has shown that A. spinulosa Sternberg has precedence. The Velebit Mts specimens compare closely with the type specimens, which were photographically reproduced by Barthel (2000, fig. 1).

\section{Annularia sphenophylloides (Zenker) Gutbier, 1821}

1833 Galium sphenophylloides Zenker, p. 398, pl. 5, figs 6-9.

1837 Annularia sphenophylloides (Zenker); Gutbier, p. 436.

1936 Annularia sphenophylloides Zenker. - Němejc, p. 11, pl. 1, fig. 15.

Material. - One small specimen of leafy shoot (Němejc Collection, National Museum Prague).

Description. - One fragment of shoot, with a whorl of $c a$ 15 small, linear to spathulate leaves, 2-3 mm long.

Remarks. - This tiny fragment was identified by Němejc (1936) as A. sphenophylloides. Although the whorl of leaves is very small, they appear to be of the shape that characterises this species.

\section{Genus Asterophyllites Brongniart, 1828a nom. cons.}

\section{Asterophyllites equisetiformis \\ (Schlotheim ex Sternberg) Brongniart, 1828a}

Figure 3F

1804 Schlotheim, pl. 1, fig. 1, pl. 2, fig. 3.

1820 Casuarinites equisetiformis Schlotheim, p. 397 (nom. illegit.). 
1825 Bornia equisetiformis Schlotheim ex Sternberg, tent. p. 28.

1828a Asterophyllites equisetiformis (Schlotheim) Brongniart, p. 159.

Material. - One small specimen of leafy shoot (10543).

Description. - Short, leafy shoot fragment $25 \mathrm{~mm}$ long. Stem slender, $<0.5 \mathrm{~mm}$ wide, with three whorls of leaves spaced $7 \mathrm{~mm}$ apart. Whorls with at least 11 slender, linear leaves (exact number of leaves impossible to confirm because the shoot is preserved side-on). Leaves $c a 13 \mathrm{~mm}$ long, attached to stem at about right angles, but then curve towards the stem apex so the distal part is at $50-60^{\circ}$ to stem. Leaf apex acute.

Remarks. - This is normally an abundant species in late Carboniferous coal floras but here only one specimen was found. Although not well preserved, it shows the characteristic slender, slightly curved leaves that characterise this species.

\section{Genus Calamites Brongniart, 1828a nom. cons.}

\section{Calamites suckowii Brongniart, 1828b}

Figure 3D

1828a Calamites Suckowi Brongniart. - Brongniart, p. 37 (nomen nudum).

1828b Calamites Suckowi Brongniart pars, p. 124, pl. 15, figs 5, 6, pl. 16, fig. 2.

1917 Calamites Suckowi Brongniart pars. - Kidston \& Jongmans, p. 107.

1936 Calamites Suckowi Brongniart. - Němejc, p. 10, pl. 3 , fig. 9 .

Material. - Ten specimens of stem compressions and pith casts. Also five specimens in the Němejc Collection in the National Museum (Prague).

Description. - Poorly preserved stem fragments with regular ribs, $1.0-1.5 \mathrm{~mm}$ apart. Nodes are poorly preserved.

Remarks. - We have essentially followed Kidston \& Jongmans (1917) in the interpretation of this species, especially in the designation of lectotypes. The specimens that we had available were too small to absolutely confirm their identification, but Němejc (1936) documented some better examples from the Velebit Mts that appear to belong to this species.

Class Marattiopsida Doweld, 2001

Order Marattiales Link, 1833

Family Psaroniaceae Unger in Endlicher, 1842
Genus Acitheca Schimper, 1879

Acitheca polymorpha (Brongniart) Schimper, 1879 Figure 4A, D

1828a Pecopteris polymorpha Brongniart, p. 56 (nomen nudum).

1834 Pecopteris polymorpha Brongniart, Brongniart p. 331, pl. 113, figs 2-5.

1879 Acitheca polymorpha (Brongniart) Schimper, p. 91, fig. 66.

1936 Acitheca polymorpha (Brongniart) Schimper. - Němejc, p. 6, text-fig. 1, pl. 1, fig. 13.

1959a Polymorphopteris polymorpha (Brongniart). - Wagner, p. 29.

2006 Acitheca polymorpha (Brongniart) Schimper. Zodrow et al., p. 271, pls 1-9, 11-14.

Material. - Four pinna fragments (specimens 10589, 10590, STR11, plus one unnumbered). Also four specimens in the Nermejc Collection in the National Museum (Prague).

Description. - Short pinna fragments with short, linguaeform pinnules $<7 \mathrm{~mm}$ long, $3 \mathrm{~mm}$ wide; one pinna fragment shows a blunt terminal with small apical pinnule. Another example has two bipinnate segments with small, rounded pinnules. Pinnules attached to rachis at $80-90^{\circ}$; some are basally constricted, others are narrowly confluent. A non-decurrent midvein runs for two-thirds the pinnule length. Well-marked lateral veins emitted from mid-vein at $c a 45^{\circ}$, bend slightly and then run in a more or less straight line to meet pinnule margin at $c a 70^{\circ}$. Veins dense, forking once or twice.

Remarks. - The taxonomy of this species, including its generic position, has most recently been analysed in detail by Zodrow et al. (2006). The pinnules in the Velebit Mts specimens are too small to show the polymorphopterid vein branching (sensu Wagner 1959a), which is one of the characteristic features of this species. Nevertheless, the linguaeform, basally constricted lateral pinnules with dense veining, and bluntly terminated ultimate pinnae with a small apical pinnule clearly point to them belonging to A. polymorpha.

\section{Genus Lobatopteris Wagner, 1959b}

\section{Lobatopteris cf. corsinii Wagner, 1959b} Figure 4B

Material. - Two pinna fragments (specimens 7, 8).

Description. - One pinna fragment (part and counterpart) 


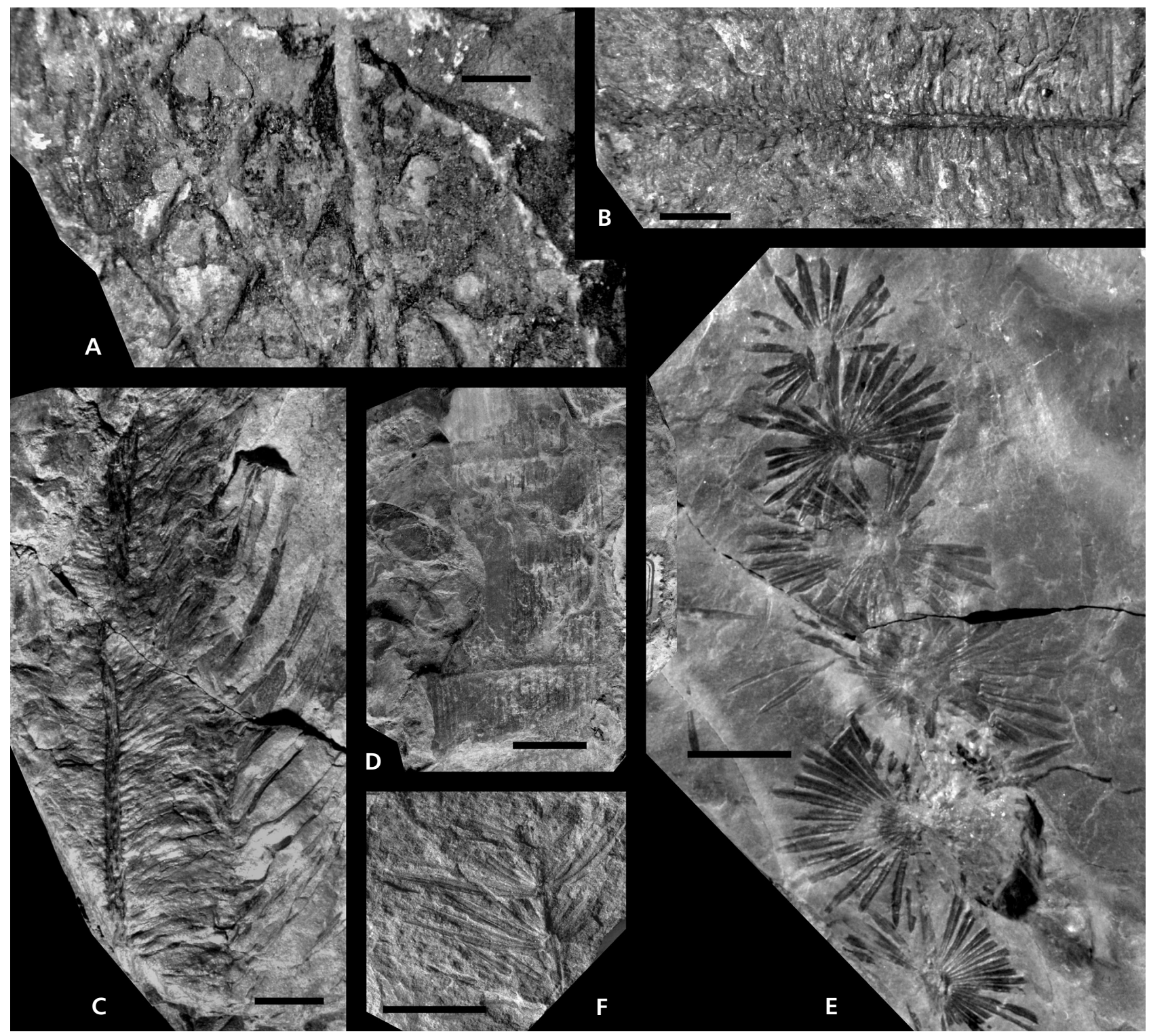

Figure 3. A, B - (?)Lepidodendron sp., Strmotić; A - surface of stem showing leaf cushions (specimen STR2); B - leafy shoot (specimen STR1). $\cdot \mathrm{C}$ - lycopsid cone, (specimen VM1). D - Calamites suckowii Brongniart, Lika (specimen LIKA98). E - Annularia spinulosa Sternberg, Strmotić, leafy shoot (specimen VM2). $\bullet \mathrm{F}-$ Asterophyllites equisetiformis (Schlotheim ex Sternberg) Brongniart, Brušane (specimen 10543). All scale bars $=10 \mathrm{~mm}$.

$45 \mathrm{~mm}$ long. Rachis relatively stout, $1.5 \mathrm{~mm}$ wide, with irregular longitudinal striae but no punctae. Elongate, linguaeform to somewhat subtriangular, pinnatifid pinnules, $<12 \mathrm{~mm}$ long, $2-3 \mathrm{~mm}$ wide, attached to rachis at $60-70^{\circ}$; pinnules lobed for most of length except for distalmost $2-3 \mathrm{~mm}$; basiscopic lobe often enlarged and somewhat basally constricted. Thick midvein runs for most of pinnule length, a little decurrent in most proximal part. Poorly preserved lateral veins grouped in fascicles, one entering each lobe.

Remarks. - This single, poorly preserved specimen is impossible to identify with certainty, but it shows some similarities with $L$. corsinii Wagner, 1959b, especially with speci- mens recently figured from Stephanian floras of northern Spain (Castro Martínez 2005a, pl. 32, pl. 33, figs 1, 2). Wagner (1959b) suggested that adjacent pinnules tend to be united at their base, but those figured by Castro Martínez show that this feature can be variable and the pinnules can sometimes be basally constricted, as in the Velebit Mts specimens.

\section{Genus Cyathocarpus Weiss, 1869 \\ Figure 4E}

1936 Asterotheca arborescens Schlotheim. - Němejc, p. 6, pl. 2, figs $1-5$. 
1936 Pecopteris (Asterotheca?) cf. paleacea Zeiller. Němejc, p. 6, pl. 1, fig. 12.

(?)1936 Asterotheca candolleana Brongniart. -Němejc, p. 7, pl. 2, figs 13, 13a.

Material. - Ten pinna fragments (specimens 10554, STR6, STR17, plus seven unnumbered).

Description. - Two short pinna fragments ca $40 \mathrm{~mm}$ long, with elongate slender pinnules attached at near to right angles to rachis. Pinnules 9-10 mm long, 2-3 mm wide, linguaeform, tapered only in most distal part, with a broadly rounded apex, and narrowly confluent at base. Thick midvein extending to pinnule apex. One specimen has simple lateral veins that appear to be emitted from midvein at $30-40^{\circ}$, curve slightly and then extend towards pinnule margin, which they met at $c a 50^{\circ}$. The other specimen has pinnules with a row of ovoid structures (sori) $c a 1 \mathrm{~mm}$ in diameter on either side of the midvein, which obscures the rest of the venation.

Two other small fragments have small, linguaeform pinnules attached at right angles to rachis. No evidence of veining can be seen.

Remarks. - These small fragments have the type of small pinnules normally associated in late Carboniferous wetland vegetation with Cyathocarpus ( $f$. Zodrow 1990). One has what appear to be reproductive structures on the pinnules, which could be of the asterothecoid-type, but no details are preserved. Similar specimens from Velebit were also recorded by Němejc (1936) as Asterotheca arborescens and Pecopteris cf. paleacea, but in our view species identification for any of these specimens is impossible.

Němejc (1936) identified a single, poorly preserved specimen as Asterotheca candolleana. It has elongate, pecopteroid pinnules very similar to what we have called ?Cyathocarpus sp. Němejc suggested that the veins were dichotomous but this is not clear from the illustration, and the original specimen has not been located.

Class Polypodiopsida Cronquist et al., 1966

Order Polypodiales Link, 1833

Family Sermayaceae Eggert \& Delevoryas, 1967

\section{Genus Oligocarpia Göppert, 1841}

\section{Oligocarpia gutbieri Göppert, 1841}

Figure 4C

1841 Oligocarpia gutbieri Göppert, p. 35, pl. 4, figs 1, 2. 1983 Oligocarpia gutbieri Göppert. - Brousmiche, p. 236, pls 57-61.
Material. - A single pinna fragment (specimen ZVEČAK1).

Description. - A $45 \mathrm{~mm}$ long near terminal fragment of tapered, bipinnate segment. Terminal part of pinna has linguaeform to somewhat subtriangular pinnules, $<3-4 \mathrm{~mm}$ long, $2 \mathrm{~mm}$ wide. In more distal positions the segments become ultimate pinnae, the longest preserved for $20 \mathrm{~mm}$ and a width of $5 \mathrm{~mm}$, obliquely attached to rachis at $c a 50^{\circ}$. Ultimate rachises striate, slender and slightly undulate. Ultimate pinnae parallel-sided for most of length, but tapered in their distal part to a distinct, rounded apical pinnule. Lateral pinnules subtriangular to linguaeform, usually basally constricted on their acroscopic side, sometimes showing minor lobbing on lateral margins; attached to rachis at $70-80^{\circ}$ in more proximal positions, $40-60^{\circ}$ in most distal positions. Veins poorly preserved but appear to be more or less straight and oblique to pinnule margin.

Remarks. - The most detailed published account of this species is by Brousmiche (1983) and it is on this that we have largely based our interpretation. Although we only had available one specimen, the distinctive subtriangular to linguaeform pinnules and oblique veining match well with the specimens figured by Brousmiche (1983).

Order and family unknown

\section{Fern fragments}

Material. - A single specimen with several pinna fragments (specimen 10587). Also one specimen in the Němejc Collection in the National Museum (Prague).

Description. - Several fragments of pinnae with a $1 \mathrm{~mm}$ wide undulate rachis, bearing tapered pinnae up to $10 \mathrm{~mm}$ long and 6-7 $\mathrm{mm}$ wide. The ultimate pinnae bear small pinnules up to 2-3 mm wide, which have two or three very acute teeth. Poortly preserved veins appear to be widely forked.

Remarks. - It is impossible to identify the small specimen in the Zagreb collection beyond it being a fern, and is being recorded simply because of its very distinctive dentate pinnules.

Němejc (1936, pl. 1, figs 2, 2a) figured a single poorly preserved specimen as Sphenopteris cf. weissi Potonié. He expressed considerable reservation about the identification of the specimen and, having examined the original specimen (in the collection of the National Museum, Prague), we regard it as totally unidentifiable.

Class Lyginopteridopsida Novák, 1961

Order Lyginopteridales Corsin, 1960

Family Lyginopteridaceae Potonié, 1900 


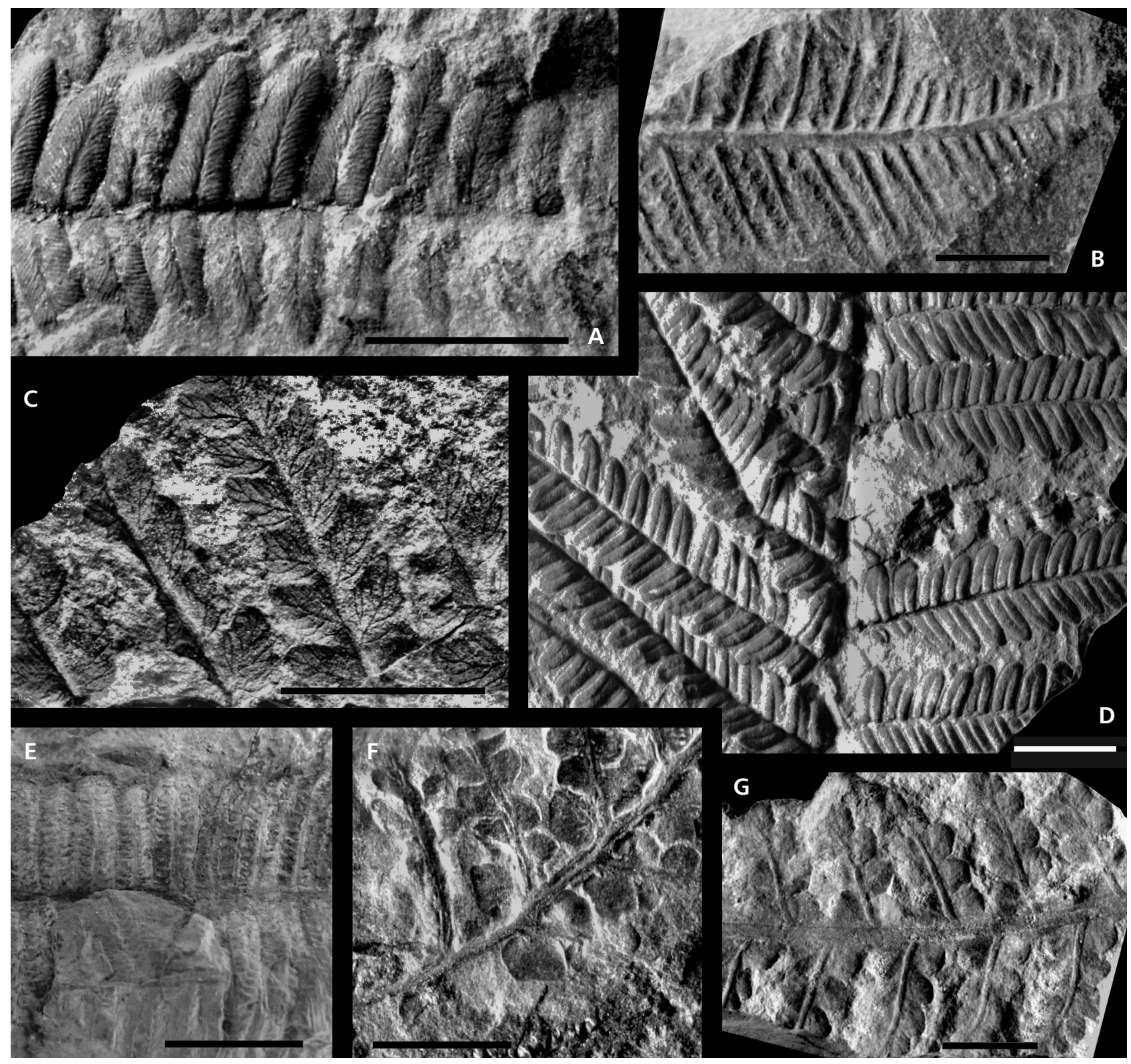

Figure 4. A, D-Acitheca polymorpha (Brongniart) Schimper, Baške Oštarije (specimen 10634); A - close-up of pinnules showing venation; D - part of bipinnate segment. • B - Lobatopteris cf. corsinii Wagner, Strmotić, fragment of ultimate pinna (specimen 7). C - Oligocarpia gutbieri Göppert, close-up of characteristic pinnules and venation, Zvečak (specimen ZVEČAK1). E - ?Cyathocarpus sp., fertile pinna, Drezgići (specimen 10554). - F - Eusphenopteris rotundiloba Němejc, Strmotić (specimen STR4). G - Dicksonites plukenetii (Sternberg) Sterzel, unknown locality (specimen 10605). All scale bars $=10 \mathrm{~mm}$.

\section{Genus Eusphenopteris Simson-Scharold, 1934} nom. cons.

\section{Eusphenopteris rotundiloba Němejc, 1937}

Figure 4F

1936 Diplotmema busquetii Zeiller. - Němejc (non Zeiller), p. 4, figs 3, 4, 4a.

1937 Eusphenopteris rotundiloba Němejc, p. 10, text-fig. 4
1975 Eusphenopteris rotundiloba Němejc. - Van Amerom, p. 82, pl. 44.

2005b Eusphenopteris rotundiloba Němejc. - Castro Martínez, p. 97, pls 67, 68.

Material. - A single pinna fragment preserved as part and counterpart (specimen STR4). Also one specimen in the Němejc Collection in the National Museum (Prague).

Description. - A pinna fragment with a flexuous, longitu- 
dinally riged rachis, $50 \mathrm{~mm}$ long. Most ultimate pinnae are preserved as stubs attached to rachis, but three show attached pinnules. Pinnules mostly isodiametric, $3 \mathrm{~mm}$ in size, round, roundly subtriangular or subrhomboidal; broadly attached to rachis, except for the most proximal pinnules which are partially basally constricted. Veins (as shown on the part specimen) thick, widely spaced and dichotomous.

Remarks. - The most detailed taxonomic treatments of the species are by Van Amerom (1975) and Castro Martínez (2005b). It is by far the most widely reported eusphenopterid from Kasimovian fossil floras of Europe. Although the pinnules often have a more vaulted limb than seen in the Velebit Mts specimens (compare with the specimens figured by Castro Martínez 2005b) this can be a variable feature (as is shown by the Van Amerom specimens; see also Doubinger et al. 1995, fig. 215).

Order Callistophytales Rothwell, 1981

Family Callistophytaceae Stidd \& Hall, 1970

\section{Genus Dicksonites Sterzel, 1881}

\section{Dicksonites plukenetii (Schlotheim ex Sternberg) Sterzel, 1881 \\ Figure $4 \mathrm{G}$}

1804 Schlotheim, pl. 10, fig. 19.

1820 Filicites Pluckenetii Schlotheim. - Schlotheim, p. 410 (nom. illegit.)

1825 Pecopteris Plukenetii Schlotheim ex Sternberg. Schlotheim, p. xix.

1881 Dicksonites Pluckeneti (Schlotheim) Sterzel, p. 223.

Material. - A single pinna fragment (specimen 10605).

Description. - Short pinna fragment $47 \mathrm{~mm}$ long and exposed showing lower surface. A $2 \mathrm{~mm}$ wide, longitudinally striate rachis bears ultimate pinnae at $c a 80^{\circ}$. Ultimate pinnae $12 \mathrm{~m}$ long, $6 \mathrm{~mm}$ wide, parallel-sided and terminated by blunt, poorly individualised apical pinnule. Pinnules roundly subtriangular to subrhomboidal with a vaulted limb, $3 \mathrm{~mm}$ long, $3 \mathrm{~mm}$ wide.

Remarks. - Although we only found one specimen, the very characteristic roundly subtriangular pinnules with a somewhat vaulted limb make the identity beyond doubt.

Class Cycadopsida Brongniart, 1843

Order Medullosales Corsin, 1960

Family Alethopteridaceae Corsin, 1960

\section{Genus Alethopteris Sternberg, 1825}

\author{
Alethopteris zeilleri (Ragot ex Remy et al.) \\ Wagner, 1964 \\ Figure 5A
}

1960 Alethopteris zeilleri Jongmans, p. 67, pl. 30, figs 154-155a (nomen nudum).

1963 Alethopteris grandini Brongniart forma zeilleri Ragot ex Remy et al.; p. 133, pl. 3, figs 1, 2 .

1964 Alethopteris zeilleri Ragot; Wagner, p. 837 et seq.

1968 Alethopteris zeilleri Ragot. - Wagner, p. 158, pls 63, 64.

Material. - 67 pinna fragments (specimens 2, 3, 6, 13, 16, STR7, STR9, STR10, STR12, STR13, STR14, STR15, plus 55 unnumbered).

Description. - Pinnae fragments up to $130 \mathrm{~mm}$ long, $20 \mathrm{~mm}$ wide, mainly parallel-sided but tapering in most distal part to a small terminal pinnule. Pinnules mostly robust, up $<16 \mathrm{~mm}$ long, $9 \mathrm{~mm}$ wide, inserted at $\mathrm{ca} 80^{\circ}$ on rachis. Pinnules mostly parallel-sided or slightly barrelled, with round apex; pinnules somewhat decurrent on basiscopic side, usually a little constricted in acroscopic side. Thick midvein only slightly decurrent at base and extending for most of pinnule length. Lateral veins leave midvein at $c a$ $45^{\circ}$, bend very quickly then extend in a more or less straight line to meet the pinnules margin at $70-90^{\circ}$. They fork once or usually twice to produce a marginal vein density of 30-35 per $\mathrm{cm}$.

Remarks. - Wagner (1968) argued that there was a progressive change in pinnule shape and venation from upper Moscovian fronds that he identified as Alethopteris grandinioides Kessler (later renamed Alethopteris pseudograndinioides Zodrow \& Cleal, 1998) to the Kasimovian $A$. zeilleri. It has since been shown that there is also a similarity in the ovules and pollenbearing organs produced by the same plants (Cleal et al. 2010).

Although this species only occurs at one locality (Strmotić) it is abundant there.

\section{Alethopteris pennsylvanica Lesquereux, 1858} Figure 5B, C

1854 Alethopteris pennsylvanica Lesquereux, p. 422 (nomen nudum).

1858 Alethopteris pennsylvanica Lesquereux, p. 864, pl. 11, figs 1, 2 .

1968 Alethopteris pennsylvanica Lesquereux. - Wagner, p. 117, pls 45-47. 

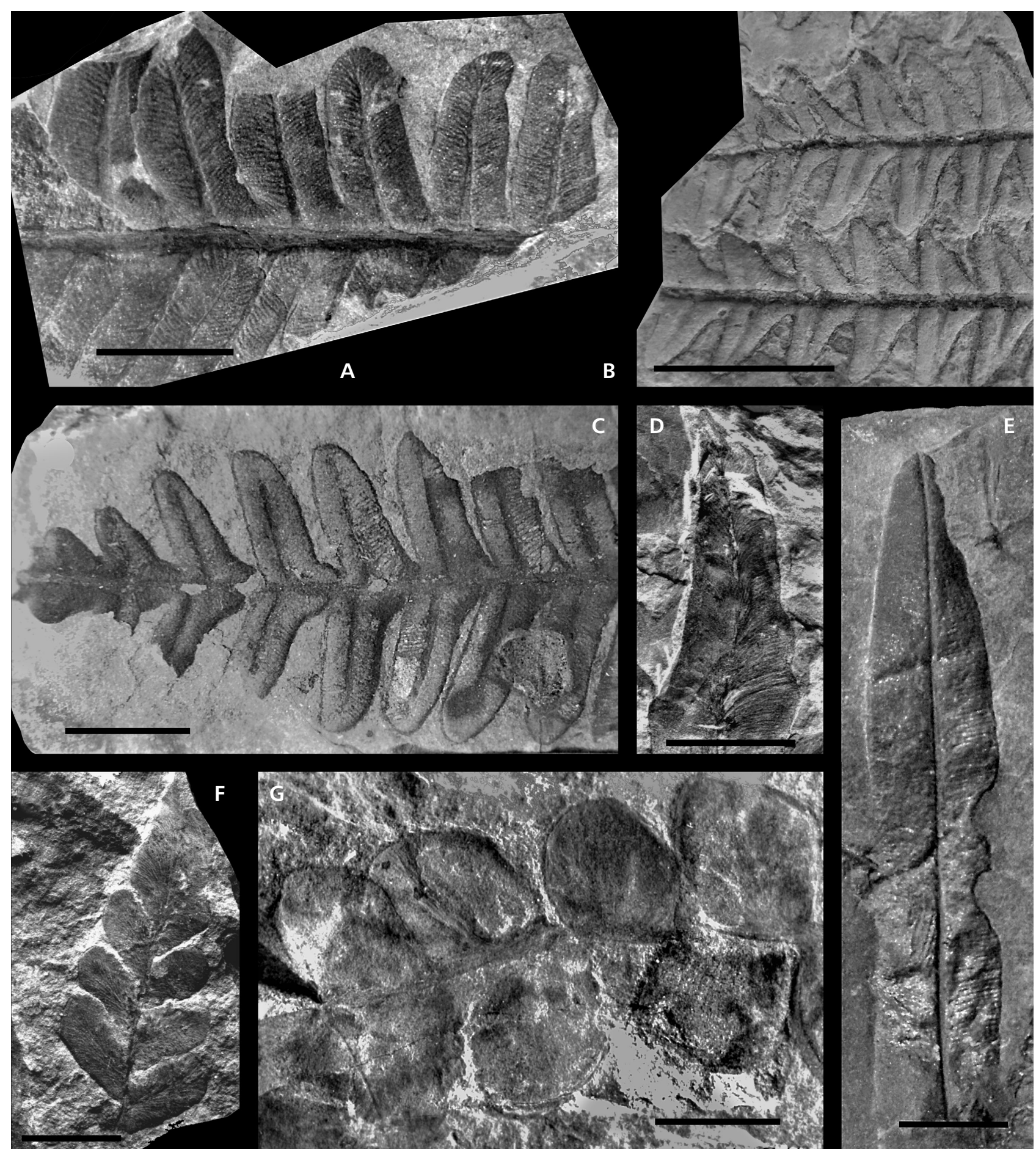

Figure 5. A - Alethopteris zeilleri (Remy et al.) Jongmans, Strmotić (specimen 3). B , C - Alethopteris pennsylvanica Wagner, Brušane; B - small pinnules probably from high in pinna (specimen 10541); C - fully developed pinnules (specimen 10528). D, F-Neuropteris sp.; D - Drezgići (specimen 10526); F - Palež W. (specimen 10566). - E - Taeniopteris carnotii Zeiller, leaf showing (?)insect damage, Strmotić (specimen 10776). $\cdot \mathrm{G}$ - Odontopteris schlotheimii Brongniart, Brušane (specimen 10575). All scale bars $=10 \mathrm{~mm}$.

Material. - Eight pinna fragments (specimens 10499, $10528,10561,10572,10579,10612,10557,10541)$.

Description. - Pinna fragments $<60 \mathrm{~mm}$ long, mainly parallel-sided but tapering in most distal part. No complete apical pinnule preserved, but one specimen (10528) shows part of what looks like a short, slender, tapered apical pinnule. Lateral pinnules inserted at $80-90^{\circ}$ along most of 
pinna, becoming more obliquely inserted $\left(50-60^{\circ}\right)$ towards pinna apex, attached to upper side of rachis. Pinnules elongate, slender, mostly $12-17 \mathrm{~mm}$ long in their fully developed form, but in one specimen at least $25 \mathrm{~mm}$ long; pinnules straight or slightly curved acroscopically, parallel-sided for most of length, tapering in distal part to an essentially round apex. Pinnules have decurrent base only on basiscopic side; adjacent pinnules separate or only narrowly confluent. Pinnule limb vaulted with thick midvein lying in deep furrow; midvein rarely decurrent and extends for most of pinnule length. Lateral veins leave midvein at $c a$ $45^{\circ}$, bend very sharply then extend in a more or less straight line to meet pinnule margin at near to right-angles. Veins mostly once forking or sometimes simple, marginal vein density ca 32 per $\mathrm{cm}$.

Remarks. - Our interpretation of this species is largely based on Wagner (1968). Our specimens bear some comparison with Alethopteris zeilleri, especially in the venation, and when the Velebit Mts collection was viewed as a whole it was difficult to tell them apart. However, when the specimens were separated according to locality of origin, it became clear that the assemblage from Brušane had consistently more slender pinnules than the A. zeilleri specimens from Strmotić.

The best-known Kasimovian Alethopteris species with slender pinnules is Alethopteris leonensis Wagner, 1964 (for more complete analyses of this species, see Wagner 1965, 1968 and Wagner \& Álvarez-Vázquez 2010b). However, A. leonensis differs in having somewhat tapered and decurrent pinnules with a less rounded apex, a less prominent midvein and less dense lateral veins. Also similar is Alethopteris ambigua Lesquereux, 1880 (?Alethopteris lesquereuxii Wagner, 1968) from the upper Moscovian Stage, but the pinnules of the latter differ in being more closely spaced, adjacent pinnules being usually non-confluent, and the lateral veins being more oblique to the pinnule margin.

A. pennsylvanica is a rare species that has only been reported from Pennsylvania, northern Spain and (now) Croatia.

\section{Genus Trigonocarpus Brongniart, 1828}

\section{Trigonocarpus aff. grandis Lesquereux, 1884 Figure 6C}

Material. - Five specimens with several compressions of ovules (specimens 9,14 , plus three unnumbered).

Description. - Large ovules $<80 \mathrm{~mm}$ long, $30 \mathrm{~mm}$ wide, ovoid with widest part about half way along length. All ovules are compressed but at least one shows a central ovoid body (?sclerotesta) $50 \mathrm{~mm}$ long, $25 \mathrm{~mm}$ wide. Surface of ovule shows irregular, longitudinal ribbing.

Remarks. - These large ovules are closely associated with Alethopteris zeilleri foliage. A similar association was noted by Doubinger et al. (1995) at St-Étienne (France) and is unlikely to be coincidental. They also compare with ovules described by Cleal et al. (2010) as Trigonocarpus grandis from the upper Middle Pennsylvanian Sydney Mines Formation of Cape Breton (Canada) and associated with Alethopteris pseudograndinioides var. subzeilleri (Wagner) Zodrow \& Cleal, 1998. The Croatian ovules appear to be a little more slender than the Canadian ones, but in view of the small number of available specimens from the Velebit Mts floras this may not be significant.

\section{Trigonocarpus sp.}

Material. - A single ovule (specimen STR3).

Description. - One small ovule, $20 \mathrm{~mm}$ long, $16 \mathrm{~mm}$ wide; preserved as external cast with a thin layer of carbon on the surface, and shows little in the way of structure.

Remarks. - A second, much smaller form of Trigonocarpus also occurs at Strmotić. It is possible that it is merely a $T$. aff. grandis ovule that had not fully developed. However, there is sufficient discrepancy in size for the small form to be recorded separately.

Family Neurodontopteridaceae Laveine ex

Cleal \& Shute, 2003

\section{Genus Neuropteris (Brongniart) Sternberg, 1825}

\section{Neuropteris sp.}

Figure 5D, F

Material. - Two pinna fragments (specimens 10526, 10566).

Description. - Pinna terminal with slender rachis and incomplete large, lanceolate apical pinnule, $17 \mathrm{~mm}$ long, $7 \mathrm{~mm}$ wide. Six obliquely-attached, linguaeform pinnules $<9 \mathrm{~mm}$ long, $6 \mathrm{~mm}$ wide; the larger pinnules and are partly constricted basally, attached to rachis by about one-third of pinnule width, and have weakly developed basiscopic auricle. Midvein extends for half pinnule length in larger pinnules. Lateral veins leave the midvein at a narrow angle and arch broadly to meet pinnule margin at $c a 50^{\circ}$. Marginal vein density ca 35 per $\mathrm{cm}$.

A second specimen has one incomplete pinnule $40 \mathrm{~mm}$ 
long, $16 \mathrm{~mm}$ wide, with gradually tapered margins (tip not preserved), a prominent acroscopic bulge and a more irregular basiscopic lobe. Midvein strongly marked, extending for most of pinnule length. Lateral veins emitted at $c a 10^{\circ}$, and arch broadly to meet pinnule margin at $70-80^{\circ}$. The veins fork at a narrow angle two or three times, to produce marginal vein density of $c a 35$ per $\mathrm{cm}$.

Remarks. - The general aspect of the pinnules of the pinnate specimen compared with Neuropteris ovata Hoffmann, 1826, an abundant species in upper Moscovian and Kasimovian floras, and Neurocallipteris neuropteroides (Göppert) Cleal et al., 1990 (= Gleichenites neuropteroides Göppert, 1836), a species from the Gzhelian Stage. The isolated, large subtriangular pinnule is also compatible with both species. Since these two species are difficult to separate without cuticles (Cleal \& Shute 1995) we have named these specimens simply as Neuropteris sp.

\section{Genus Odontopteris (Brongniart) Brongniart, 1831}

\section{Odontopteris schlotheimii Brongniart, 1828a}

Figures 5G, 6B

1804 Schlotheim, p. 33, pl. 3, figs 5, 6.

1820 Filicites osmundaeformis Schlotheim, p. 413 (nomen illegit.).

1828a Odontopteris schlotheimii Brongniart; Brongniart, p. 60.

1936 Odontopteris subcrenulata (Rost) Zeiller. - Němejc (non Rost), p. 9, pl. 2, fig. 15.

2006 Odontopteris schlotheimii Brongniart. - Barthel, p. 56, figs $138-143$.

Material. - Two pinna fragments (specimens 10575, 10577).

Description. - Two pinna fragments with squat pinnules, 7-12 mm long, 7-10 mm wide, squat-linguaeform to rounded, basally slightly constricted or broadly attached to rachis. Midvein absent, subsidiary veins apparently arising directly from rachis. Veins relatively thick, only slightly arched and fork two to three times. Marginal vein density ca 20 per $\mathrm{cm}$ on pinnule apex.

Remarks. - This is a very distinctive species, assumed to be medullosalean, probably equivalent to the anatomically preserved fossil-species Medullosa endocentrica Hamer \& Rothwell, 1988 (see Cleal \& Shute 2012). The most detailed taxonomic analysis is by Barthel (2006), who showed that the name $O$. schlotheimii has to take precedence over Odontopteris osmundaeformis Schlotheim.

The only species with which this is likely to be confused is Odontopteris cantabrica Wagner, which was first described from the lower Stephanian Stage of northern Spain (Wagner et al. 1969). Wagner (in Wagner et al. 1969) suggested that it might be possible to regard $O$. cantabrica as a variety of $O$. osmundaeformis (i.e. O. schlotheimii), but, in view of the long stratigraphical gap between the known ranges of the two forms, it is preferable to regard them as distinct fossil-species. It is also noteworthy that $O$. cantabrica does not have the large, neuropteroid pinnules that form such a distinctive part of the $O$. schlotheimii fronds. Cuticle evidence may help here but, although they are known for O. cantabrica (Cleal et al. 2007; Zodrow \& Mastalerz 2009; Zodrow et al. 2009, 2012) they are unknown for $O$. schlotheimii.

Němejc (1936) figured a poorly preserved odontopteroid from the Velebit Mts with large pinnules as Odontopteris subcrenulata. The figured photograph does not show the venation clearly enough, but it seems most likely that it belongs to the species we are calling here O. schlotheimii.

Family Cyclopteridaceae Corsin, 1960

\section{Genus Callipteridium (Weiss) Zeiller in Renault \& Zeiller, 1888}

\section{Callipteridium pteridium (Schlotheim) Zeiller in Renault \& Zeiller, 1888}

Figure 6A

1804 Schlotheim, p. 59, pl. 14, fig. 27.

1820 Filicites pteridius Schlotheim, p. 406 (nom. illegit.).

1832 Filicites pteridius Schlotheim, p. 8, pl. 14, fig. 27.

1888 Callipteridium pteridium (Schlotheim). - Zeiller in Renault \& Zeiller, p. 194, pl. 19, figs 1-3.

1936 Callipteridium pteridium Schlotheim. - Němejc, p. 8 , pl. 2, figs 7,8 .

Material. - Nine pinna fragments (specimens 4, 10497, 10530, 10531, 10545, 10634, X11, X12, X13). Also nine specimens in the Nermejc Collection in the National $\mathrm{Mu}-$ seum (Prague).

Description. - Fragments of bipinnate segments $<70 \mathrm{~mm}$ long and wide. Penultimate rachis longitudinally striate, 2-3 mm wide, with ultimate rachises attached at $60-80^{\circ}$. Ultimate pinnae $<10 \mathrm{~mm}$ wide, parallel-sided for most of length, but tapered gradually in their distal part to an elongate apical pinnule. Lateral pinnules mostly 5-6 mm long, 2-3 mm wide in their fully-developed form, attached to upper side of rachis at $70-80^{\circ}$, becoming more oblique $\left(<50^{\circ}\right)$ in the distal parts of pinnae. Pinnules somewhat vaulted, linguaeform, or in distal parts of pinnae sometimes subtriangular, straight or somewhat acroscopically curved, with 
broadly round apex. Pinnule base not significantly decurrent, with adjacent pinnules being narrowly confluent. Thick midvein lies in a shallow furrow and extends for $c a$ two-thirds of pinnule length. Lateral veins emitted from midvein at a narrow angle ( $\left.\mathrm{ca} 10-20^{\circ}\right)$, bend slightly and meet pinnule margin at $70-80^{\circ}$ on acroscopic side, $60-70^{\circ}$ on basiscopic side. Lateral veins fork once, sometimes twice in larger pinnules (the second fork usually being on the distal branch produced by the first fork) to produce a marginal vein density of 38-40 per $\mathrm{cm}$.

Remarks. - The taxonomy and nomenclature of Callipteridium is in confusion, with its relationship with Callipteridium gigas (Gutbier) Weiss, 1870 (= Pecopteris gigas Gutbier, 1849), Callipteridium striatum Wagner, 1964 and Callipteridium zeilleri Wagner, 1964 remains unresolved. Our single specimen provides no helpful evidence on this matter. However, C. pteridium is the earliest legitimately published of these names, and the Velebit Mts specimens compare well with typical specimens of that species ( $c f$. Wendel 1980).

Family uncertain

\section{Genus Taeniopteris Brongniart, 1831}

Taeniopteris carnotii Zeiller in Renault \& Zeiller, 1888 Figure 5E

1888 Taeniopteris carnoti Zeiller; Zeiller in Renault \& Zeiller, p. 282, pl. 22, fig. 10.

1936 Taeniopteris carnoti Zeiller. - Němejc, p. 9, pl. 1, fig. 14, pl. 2, fig. 14 (not 17 as quoted in text).

2012 Taeniopteris carnoti Zeiller. - Jarzembowski, pl. 1.

Material. - A single leaf preserved as part and counterpart (specimen 10776).

Description. - A leaf fragment $68 \mathrm{~mm}$ long, $12 \mathrm{~mm}$ wide, parallel-sided for most of length, tapering in distalmost $25 \mathrm{~mm}$ to a narrowly rounded apex. Leaf limb essentially flat. Thick midvein extends for all of leaf length. Lateral veins emitted from midvein at $45^{\circ}$, bend quickly and then run in an essentially straight line to meet the leaf margin at $80^{\circ}$; marginal vein density $c a$ 22 per $\mathrm{cm}$.

Remarks. - Němejc (1936) identified these Velebit Mts specimens as $T$. carnotii, which he regarded as having similar sized leaves and vein density. They also compare in leaf shape with Taeniopteris jejunata Grand'Eury, 1877 (e.g. Doubinger et al. 1995, figs 338, 339; Castro Martínez 2005b, pl. 33) but this species tends to have somewhat less dense veining (usually $<20$ per $\mathrm{cm}$ ). A better comparison is with the fragment figured by Fritz et al. (1990, fig. 97) as $T$. jejunata, which has a venation nearer to that of the Velebit Mts specimen.

\section{Other species recorded by Němejc (1936)}

Not all of the specimens described by Němejc (1936) have been located. Consequently, we have not been able to verify all of the species recorded in his study: Ptychocarpus unitus (Brongniart) Weiss, Nemejcopteris feminaeformis (Schlotheim ex Sterzel) Barthel, Crossotheca pinnatifida (Gutbier) Potonié, Linopteris duplex Bertrand, Cyclopteris sp., Cordaites palmaeformis Göppert, Cordaicaarpus ovoideus (Göppert \& Berger) Seward and Carpolithus sp.

We could not locate the specimen that Němejc (1936, pl. 1, fig. 10) figured as Pecopteris plumosa (Artis) Brongniart, but another specimen that he labelled as this species closely resembles what we call ?Cyathocarpus sp.

Němejc (1936) recorded numerous specimens as Alethopteris bohemica Franke. However, when the specimens themselves were examined, most had a far less dense venation than is characteristic of that species, and could mostly be attributed to either Alethopteris zeilleri or Alethopteris pennsylvanica.

\section{Discussion}

\section{Biostratigraphy}

The stratigraphical ranges of the biostratigraphically important species that we have identified in the Velebit Mts flora are shown in Fig. 7, plotted against the now standard set of biozones for the Upper Pennsylvanian Series (see Wagner 1984, Wagner \& Alvarez-Vázquez 2010a). This clearly indicates that they belong to either the S. angustifolium or A. conferta Zone and, if the identity of the Lobatopteris corsinii can be confirmed, the evidence strongly points to the former. Wagner (1984) regarded the S. angustifolium Zone as an indicator of the Stephanian C Stage (now Substage) but he has subsequently revised this downwards to the Stephanian B Substage (Wagner 1998, Wagner \& Alvarez-Vázquez 2010a). According to Wagner \& Alvarez-Vázquez (2010a) this would equate to the upper Kasimovian or lowermost Gzhelian Stage in the IUGS chronostratigraphy for the Carboniferous System (Heckel \& Clayton 2006). Microfaunal data (Fig. 2; Kochansky-Devidé 1955, 1970; Merino-Tomé et al. 2009; Sremac 2012) have indicated a very similar age for these Croatian deposits. 


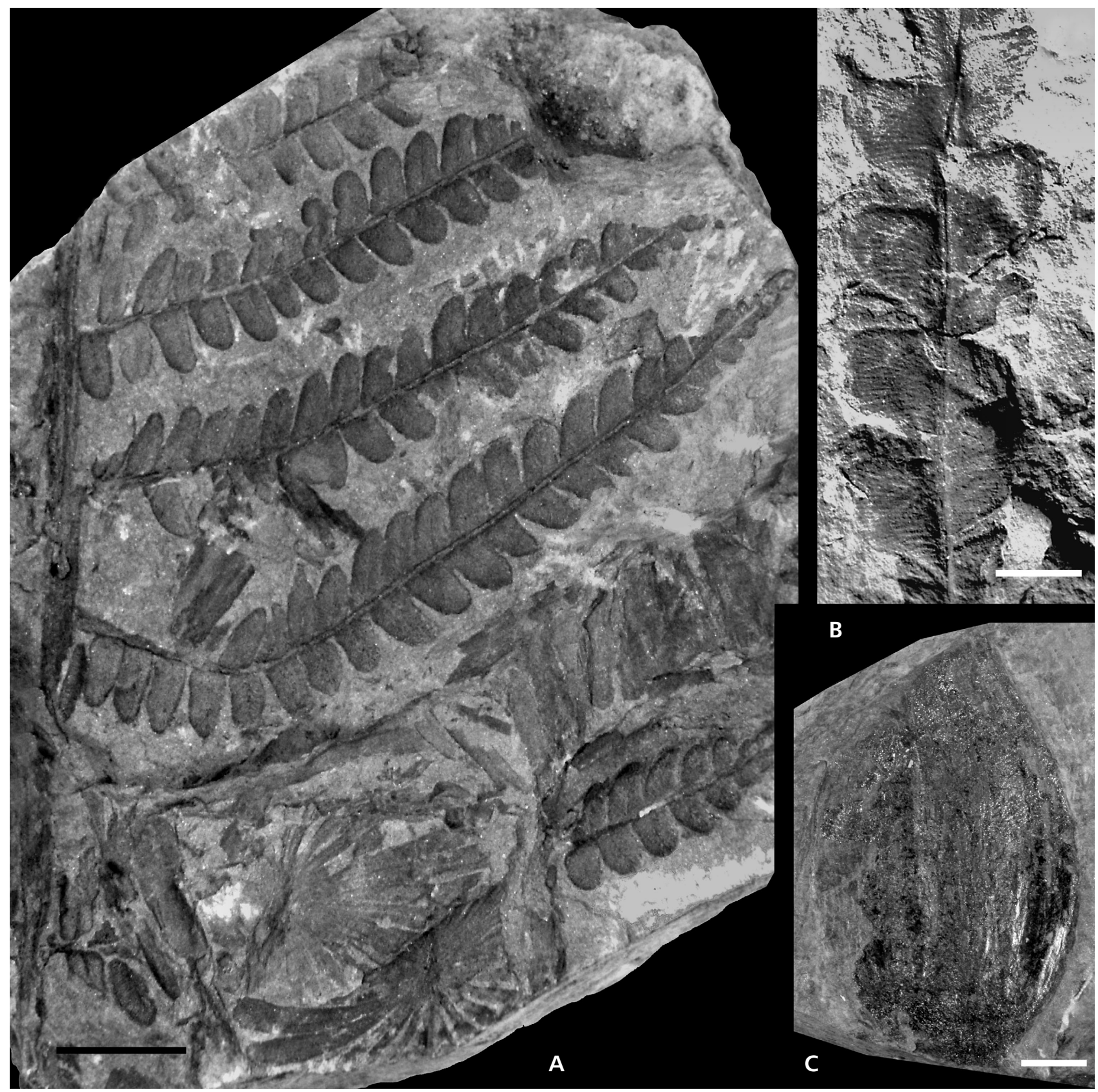

Figure 6. A - Callipteridium pteridium (Schlotheim) Zeiller, Oštarije (specimen 10545). B - Odontopteris schlotheimii Brongniart, Brušane (specimen 10577). $\bullet$ C - Trigonocarpus aff. grandis Lesquereux, Strmotić (specimen STR). All scale bars $=10 \mathrm{~mm}$.

\section{Composition of fossil flora}

Table 2 summarises the relative abundances of the 19 fossil species that we have seen in the Carboniferous floras from the Velebit Mts. This should not be regarded as a systematically sampled census but was merely a count of the number of specimens in the collections of the Croatian Natural History Museum and the National Museum (Prague). It nevertheless provides a reasonable impression of the overall balance of the plant groups present. It is immedia- tely evident that the flora is dominated by medullosaleans (mainly Alethopteris), sphenophytes and marattialean ferns (notably ?Cyathocarpus), which together make up over $90 \%$ of the assemblage. Notable absentees are Sphenophyllum and cordaitanthaleans (although fragments of both were reported from here by Němejc 1936).

One of the few sources of statistical data on Stephanian floras with which these figures can be compared is in Castro Martínez (2005a), who gave comparable data from the Stephanian B La Magdalena Coalfield in northern Spain. 
Table 2. Census of plant fossils from the Velebit Mts Carboniferous floras, according to species and major plant groups. This is based on specimens in both the Croatian Natural History Museum (Zagreb) and National Museum (Prague). N - Number of specimens.

\begin{tabular}{|c|c|c|c|}
\hline & $\mathrm{N}$ & Major plant group & $\mathrm{N}$ \\
\hline ?Lepidodendron sp. & 11 & Lycopsids & 11 \\
\hline Annularia spinulosa & 18 & \multirow{4}{*}{ Sphenophytes } & \multirow{4}{*}{35} \\
\hline tAnnularia sphenophylloides & 1 & & \\
\hline Asterophyllites equisetiformis & 1 & & \\
\hline Calamites suckowii & 15 & & \\
\hline Acitheca polymorpha & 8 & \multirow{3}{*}{ Marattialean ferns } & \multirow{3}{*}{21} \\
\hline Lobatopteris cf. corsinii & 2 & & \\
\hline ?Cyathocarpus spp. & 11 & & \\
\hline Oligocarpia gutbieri & 1 & \multirow{2}{*}{ Other ferns } & \multirow{2}{*}{3} \\
\hline Fern fragment & 2 & & \\
\hline Eusphenopteris rotundiloba & 2 & \multirow{2}{*}{ Lyginopteridaleans } & \multirow{2}{*}{2} \\
\hline Dicksonites plukenetii & 1 & & \\
\hline Alethopteris zeilleri & 76 & \multirow{7}{*}{ Medullosaleans } & \multirow{7}{*}{122} \\
\hline Alethopteris pennsylvanica & 18 & & \\
\hline Trigonocarpus aff. grandis & 5 & & \\
\hline Trigonocarpus sp. & 1 & & \\
\hline Neuropteris sp. & 2 & & \\
\hline Odontopteris schlotheimii & 2 & & \\
\hline Callipteridium pteridium & 18 & & \\
\hline Taeniopteris carnotii & 1 & (?)Cycadaleans & 1 \\
\hline
\end{tabular}

These Spanish floras also tend to be dominated by medullosaleans, sphenophytes and Marattiales, although not to the same degree (usually together comprising 50-70\% of the total), but also with significant components of Sphenophyllum and non-marattialean ferns. In contrast, the Westphalian floras from the Variscan Foreland (such as analysed by Davies 1929, Cleal et al. 2012) consistently have a much higher proportion of sphenophytes (often over $50 \%$ of the total), lycopsids and cordaitanthaleans, presumably reflecting the wetter substrates in these earlier wetland habitats.

\section{Floristic comparisons}

Floras of comparable age are relatively poorly known in Euramerica, mostly situated in the eastern part of the Euramerican tropical belt (Fig. 8).

The most extensively collected are from northern Spain, notably from the Villablino Coalfield and, although no definitive monograph on these floras has been published, there are numerous published papers (as summarised by Wagner \& Alvarez-Vázquez 2010a). The list of Stephanian B floras from Villablino given by Wagner \& Alvarez-Vázquez (2010a) is rather longer than that from the Velebit Mts, mainly because they have been derived through more extensive collecting from more localities, but they include virtually all of the species found in the Velebit Mts sites. The only exceptions are Odontopteris schlotheimii, which based on the Wagner \& AlvarezVázquez (2010a) records, is totally absent from Spain, and Taeniopteris carnotii, which is a very rare species. A number of other similar but less diverse floras are also listed by Wagner \& Alvarez-Vázquez (2010a) mainly from the western and northeastern margins of the Cantabrian Basin.

The Pramollo Group (Kasimovian-Gzhelian) floras of the Carnic Alps are of broadly similar age to the Croatian floras and reportedly share a number of taxa, such as Annularia spinulosa, Acitheca polymorpha, Eusphenopteris rotundiloba [recorded as Eusphenopteris nummularia (Gutbier) Novik], Dicksonites plukenetii, Alethopteris zeilleri [recorded as Alethopteris serlii (Brongniart) Göppert] and Callipteridium pteridium (Fritz et al. 1990; Fritz \& Krainer 2006, 2007; Ronchi et al. 2012). However, there are also many notable differences, such as the greater diversity of lycopsids, sphenophylls and marattialean ferns in the Carnic floras.

There are a number of contemporaneous coal-bearing sequences in the Massif Central and surrounding areas of southern France (as summarised by Vetter 1986). Of these, the St-Étienne Formation (Grüner Member) of St-Étienne and the Bourran Formation of Decazeville have yielded the best-documented floras (e.g. Vetter 1968, Doubinger et al. 1995). The St-Étienne Formation has most of the species found in the Velebit Mts with the notable exceptions of Eusphenopteris rotundiloba, Dicksonites plukenetii and Odontopteris schlotheimii (although there is the very similar species Odontopteris pseudoschlotheimii de Maistre). From Doubinger et al. (1995, table 8) it would seem that the St-Étienne floras also have relatively high proportions of sphenophytes and alethopterid medullosaleans, but in contrast to the Velebit Mts floras there are also abundant marattialean ferns, cordaites and conifers, and Taeniopteris is also more abundant. The situation is similar in the Bourran Formation, except that the alethopterid medullosaleans are much rarer, and the odontopteroid medullosaleans and callistophytaleans somewhat more abundant.

The Breitenbach Formation in Saarland (Germany) has also yielded a $S$. angustifiolia Zone flora (Hemmer 1920, Doubinger 1956, Cleal 2008). Whilst sharing many species in common with the Velebit Mts fossil flora (e.g. Annularia spinulosa, Acitheca polymorpha, Odontopteris schlotheimii, Callipteridium pteridium) the former lacks several of the alethopterid species, Eusphenopteris rotundiloba and Dicksonites plukenetii.

There are some similarities with the floras from the Rosice-Oslavany Formation in the lower part of the Boskovice Basin succession in southern Bohemia (Šimůnek \& Martínek 2009). Both share a number of taxa including 
Christopher J. Cleal et al. • Pennsylvanian fossil flora from SW Croatia

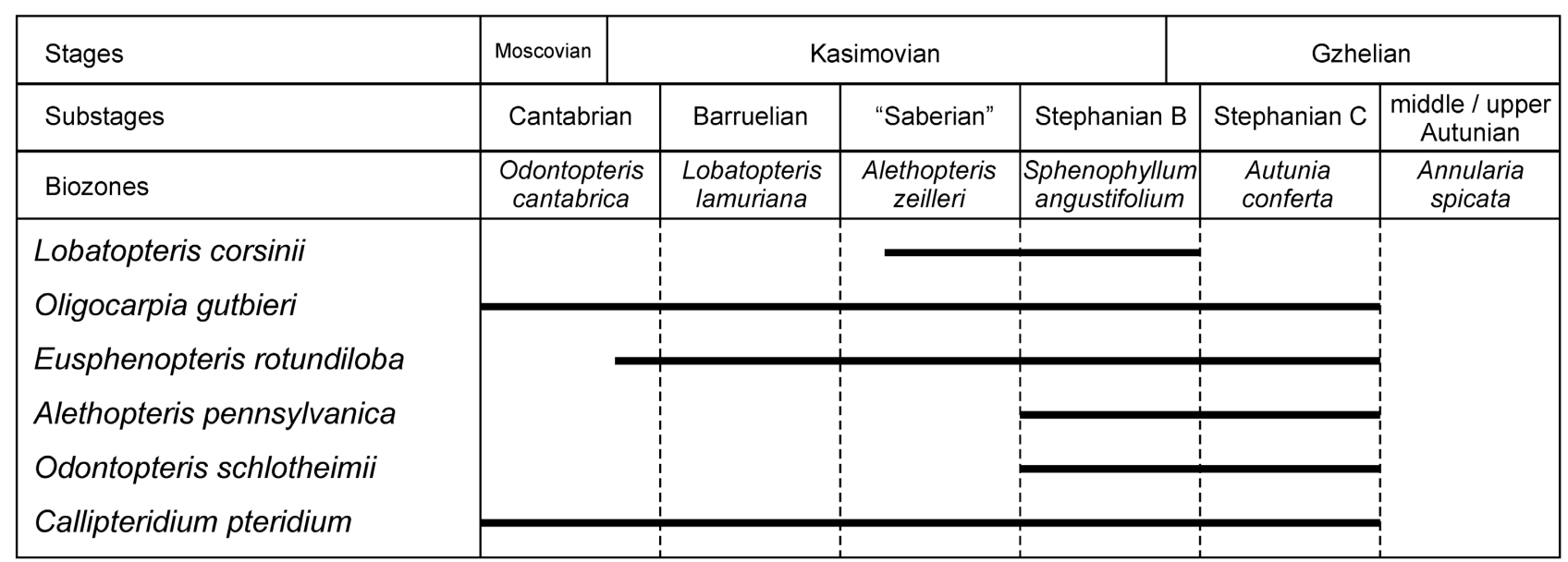

Figure 7. Stratigraphical ranges of the six stratigraphically informative species in the Upper Pennsylvanian fossil flora from the Velebit Mts, Croatia. The ranges of Calamites suckowii, Annularia spinulosa, Asterophyllites equisetiformis, Acitheca polymorpha, Dicksonites plukenetii and Alethopteris zeilleri are not shown as they range throughout the stratigraphical interval represented; and the range of Taeniopteris carnotii is not known in any detail. The ranges are plotted against the biozones proposed by Wagner (1984) and modified by Wagner \& Alvarez-Vázquez (2010a). The correlation of the zones with the Heerlen substages and IUGS stages is based on Wagner (1998) and Wagner \& Alvarez-Vázquez (2010a).

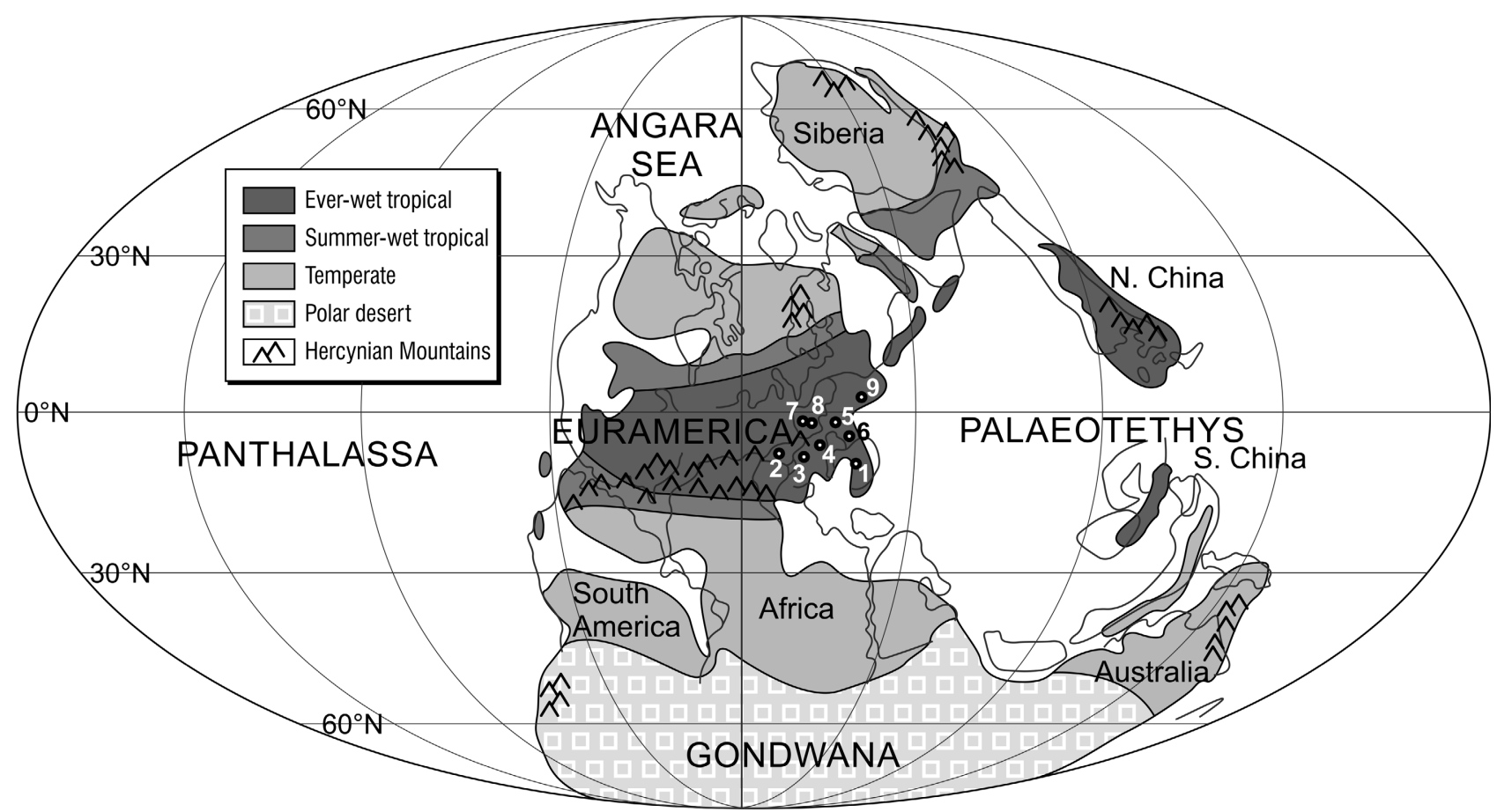

Figure 8. Localities with Stephanian B flora in Euramerica. Palaeogeographic reconstruction based upon Falcon-Lang (2003), DiMichele et al. (2010). 1. Croatia - Velebit Mts And Lika region; 2. Spain - Villablino and La Magdalena; 3. France - Massif Central; 4. Germany - Saarland, Saxony-Anhalt; 5. Austria - Carnic Alps; 6. Slovenia - Karavanke Mts; 7. Czech Republic-Bohemia Basin; 8. Poland - Intrasudetic Basin; 9. Ukraine - Donets Basin.

Annularia spinulosa, Asterophyllites equisetiformis, Acitheca polymorpha, Dicksonites plukenetii, Alethopteris zeilleri and Odontopteris schlotheimii. The Boskovice floras tend to have a far higher proportion of marattialean fern remains than seen in the Velebit Mts, as well as having a much wider range of medullosalean pteridosperms (but unlike the Croatian floras are not dominated by alethopterids).
Also of similar S. angustifolia Zone age is the Líně Formation in the Central and Western Bohemia Basin (Pešek 1994). Based on the floral species list from here by Šimůnek (in Pešek 1994, table 4) there are a number of species in common including Alethopteris zeilleri, Odontopteris schlotheimii, Callipteridium pteridium, Dicksonites plukenetiii and Acitheca polymorpha. However, 
there are a number of discrepancies, notably the absence from the Líně Formation of Alethopteris pennsylvanica, Oligicarpia gutbieri, Eusphenopteris rotundiloba, Lobatopteris corsinii, Annularia spinulosa and any lycopsids (other than Asolanus camptotaenia), and the absence from the Velebit Mts of conifers and cordaites. This may reflect the rather different ecological setting of the Líně Formation, which was formed in a fluvio-lacustrine environment in an intra-montane setting (as summarised in Pešek 1994) and would have incorporated remains of vegetation from surrounding habitats with drier substrates (e.g. conifers and cordaites), whereas the taxa present in the Velebit Mts but not in the Líně Formation probably represent more lowland, wetter substrate vegetation.

Wagner (1984) reported that similar aged floras occur in the area of Wettin (Saxony-Anhalt, Germany) and according to Remy et al. (1963) the Wettin Formation includes Alethopteris zeilleri and Callipteridium pteridium. However, there has been no recent taxonomic review of these floras so a detailed comparison is impossible.

The Gzhelian Stage in the Donets Basin (Ukraine) has abundant floras that should be approximately contemporaneous with those from the Velebit Mts (Novik 1952) but none of the associations summarised and in part described by Shchegolev $(1975,1991)$ are similar. Unlike the Croatian floras, ferns and sphenophylls dominate, and medullosaleans are relatively rare and Alethopteris is absent [the only alethopterid recorded from these strata by Novik (1952) is Alethopteris discreta (Weiss) Zalessky, a species which Wagner \& Castro Martínez, 1998 have transferred to Neuropteris obtusa (Brongniart) Wagner \& Castro Martínez]. The contemporaneous floras from the Caucasus described in detail by Shchegolev (1979) are similarly rich in ferns and relatively rare in medullosaleans.

\section{Conclusions}

Continental interbeds within the mainly marine Upper Pennsylvanian sequence of the Velebit Mts and Lika region of Croatia have yielded abundant plant macrofossils indicating a Stephanian B (late Kasimovian or earliest Gzhelian) age. They are thus remains of some of the youngest Pennsylvanian wetland vegetation still remaining in Europe, as landscape changes and increased drainage triggered by $\mathrm{Va}-$ riscan tectonics caused the biome to contract and fragment. This was also when the wetland biome was migrating east into Cathaysia, and it has been argued that the relatively localised distribution of the European wetlands at this time may have acted as a taxonomic bottleneck that caused the differences in overall taxonomic balance between the Pennsylvanian Euramerican and successor Permian Cathaysian vegetation (Hilton \& Cleal 2007). Understanding Late
Pennsylvanian Euramerican plant biogeography is clearly important for interpreting this major biome migration, as well as the transition from Palaeophytic to Mesophytic floras (sensu Cleal \& Cascales-Miñana 2014).

The Croatian assemblage compares most closely with similar age floras in northern Spain, notably from the Villablino Coalfield, and the Pramollo Group of the Carnic Alps. It epitomises the lowland vegetation that developed during latest Carboniferous times on the southern side of the Variscan Mountains, along the northern coast of the Palaeotethys. In contrast, the fossil floras of similar age from the intramontane basins, notably of France, Germany and the Czech Republic, tend to have a greater diversity of marattialean ferns, and also often to include sphenophylls, cordaites and conifers, probably reflecting the higher elevation of these basins.

\section{Acknowledgements}

We would like to thank Erwin Zodrow (University of Cape Breton, Canada) and a second, anonymous referee for helpful comments on the paper. The first author (CJC) would also like to thank the Croatian Geological Society for support during his visit to the Croatian Natural; History Museum in Zagreb. This is a contribution to IGCP 575: Pennsylvanian terrestrial habitats and biotas of Southeastern Euramerica.

\section{References}

Agardh, C.H. 1825. Aphorismi botanici. Classes plantarum, pars $1.12 \mathrm{pp}$. Berling, Lund.

Amerom, H.W.J. van 1975. Die eusphenopteridischen Pteridophyllen aus der Sammlung des Geologischen Bureaus in Heerlen, unter besonderer Berücksichtigung ihrer Stratigraphie bezüglich des südlimburger Kohlenreviers. Mededelingen Rijks Geologische Dienst, Serie C-III-1 7, $1-202$.

BARthel, M. 2000. Annularia stellata oder Annularia spinulosa? Veröffentlichungen Naturkundemuseum Erfurt 19, 37-42.

Barthel, M. 2004. Die Rotliegendflora des Thüringer Waldes. Teil 2: Calamiten und Lepidophyten. Veröffentlichungen des naturhistorisches Museums Schleusingen 19, 19-48.

BARTHEL, M. 2006. Die Rotliegendflora des Thüringer Waldes. Teil 4: Farnsamer und Farnlaub unbekannter taxonomischer Stellung. Veröffentlichungen des naturhistorisches Museums Schleusingen 21, 33-72.

Brongniart, A. 1828a. Prodrome d'une Histoire des végétaux fossiles. 223 pp. F.G. Levrault, Paris \& Strasbourg.

Brongniart, A. 1828b. Histoire des végétaux fossiles 1(1-2), 1-136. G. Dufour \& E. d'Ocagne, Paris.

Brongniart, A. 1831. Histoire des végétaux fossils 1(5-6), 209-264. G. Dufour \& E. d'Ocagne, Paris.

Brongniart, A. 1834. Histoire des végétaux fossiles 1(8-9), 289-336. G. Dufour \& E. d'Ocagne, Paris.

Brongniart, A. 1843. Énumération des genres de plantes 
cultivés au Muséum d'histoire naturelle de Paris. 136 pp. Fortin, Mason \& Cie, Paris.

BRousmiche, C. 1983. Les fougères sphénoptéridiennes du bassin houiller Sarro-Lorrain. 480 pp. Société Géologique du Nord, Villeneuve-d'Ascq.

Castro Martínez, P. 2005a. La flora estefaniense B de La Magdalena (León, España), un referente europeo. Tomo I: Antecedentes y análisis florístico. 251 pp. Instituto Geológico y Minero de España, Madrid.

Castro Martínez, P. 2005b. La flora estefaniense B de La Magdalena (León, España), un referente europeo. Tomo II: Descripción sisteática de las Gimnospermas. 229 pp. Instituto Geológico y Minero de España, Madrid.

ClEAL, C.J. 2008. Macrofloral biostratigraphy of the Ottweiler Group in Saar-Lorraine and its consequences for Stephanian palynostratigraphy and geochronology. Studia Geologica Polonica 129, 9-23.

Cleal, C.J. \& Cascales-Miñana, B. 2014. Composition and dynamics of the great Phanerozoic Evolutionary Floras. Lethaia. DOI 10.1111/let.12070

Cleal, C.J. \& Shute, C.H. 1995. A synopsis of neuropteroid foliage from the Carboniferous and Lower Permian of Europe. Bulletin of the Natural History Museum 51, 1-52.

Cleal, C.J. \& Shute, C.H. 2003. Systematics of the Late Carboniferous medullosalean pteridosperm Laveineopteris and its associated Cyclopteris leaves. Palaeontology 46, 353-411. DOI 10.1111/1475-4983.00303

Cleal, C.J. \& Shute, C.H. 2012. The systematic and palaeoecological value of foliage anatomy in Late Palaeozoic medullosalean seed-plants. Journal of Systematic Palaeontology 10, 765-800. DOI 10.1080/14772019.2011.634442

Cleal, C.J., Shute, C.H. \& Zodrow, E.L. 1990. A revised taxonomy for Palaeozoic neuropterid foliage. Taxon 39, 486-492. DOI $10.2307 / 1223109$

Cleal, C.J. \& Thomas, B.A. 1999. Tectonics, tropical forest destruction and global warming in the Late Palaeozoic. Acta Palaeobotanica, Supplement 2, 17-19.

Cleal, C.J. \& Thomas, B.A. 2005. Palaeozoic tropical rainforests and their effect on global climates: is the past the key to the present? Geobiology 3, 13-31. DOI 10.1111/j.1472-4669.2005.00043.x

Cleal, C.J., Uhl, D., Cascales-Miñana, B., Thomas, B.A., Bashforth, A.R., King, S.C. \& Zodrow, E.L. 2012. Plant biodiversity changes in Carboniferous tropical wetlands. Earth-Science Reviews 114, 124-155. DOI 10.1016/j.earscirev.2012.05.004

Cleal, C.J., Zodrow, E.L. \& Mastalerz, M. 2010. An association of Alethopteris foliage, Trigonocarpus ovules and Bernaultialike pollen organs from the Middle Pennsylvanian of Nova Scotia, Canada. Palaeontographica, Abteilung B 283, 73-97.

Cleal, C.J., Zodrow, E.L. \& ŠimưNeK, Z. 2007. Leaf cuticles from the Pennsylvanian-aged medullosalean Odontopteris cantabrica Wagner. Acta Palaeobotanica 47, 327-337.

Corsin, P. 1960. Classification des Ptéridophytes et des Ptéridospermophytes du Carbonifère. Bulletin de la Société géologique de France, Série 7 2, 566-572.

Cronquist, A., Takhtajan, A. \& Zimmermann, W. 1966. On the higher taxa of Embryobionta. Taxon 15, 129-134. DOI $10.2307 / 1217531$
DAVIES, D. 1929. Correlation and palæontology of the Coal Measures in east Glamorganshire. Philosophical Transactions of the Royal Society of London, Series B 217, 91-153.

DOI 10.1098/rstb.1929.0003

DiMichele, W.A., Cecil, C.B., Montañez, I.P. \& Falcon-Lang, H.J. 2010. Cyclic changes in Pennsylvanian paleoclimate and effects on floristic dynamics in tropical Pagaea. International Journal of Coal Geology 83, 329-344.

DOI 10.1016/j.coal.2010.01.007

Doubinger, J. 1956. Contribution à l'étude des flores AutunoStéphaniennes. Mémoires de la Société géologique de France, N. S. $75,1-180$.

Doubinger, J., Vetter, P., Langiaux, J., Galtier, J. \& Broutin, J. 1995. La flore fossile du bassin houiller de Saint-Étienne. Mémoires du Museum National d'Histoire Naturelle 164, 1-357.

Doweld, A. 2001. Prosyllabus Tracheophytorum. Tentamen systematis plantarum vascularium (Tracheophyta). $110 \mathrm{pp}$. Geos, Moscow.

Dumortier, B.C. 1829. Analyse des familles des plantes, avec l'indication des principaux genres qui s'y rattachent. $104 \mathrm{pp}$. J. Casterman, Tournay. DOI 10.5962/bhl.title.48702

EgGert, D.A. \& Delevoryas, T. 1967. Studies of Paleozoic ferns: Sermeya, gen. nov. and its bearing on filicalean evolution in the Paleozoic. Palaeontographica, Abteilung B 120, $169-180$.

ENDLICHER, S.L. 1842. Genera plantarum secundum ordines naturales deposita, suppl. 2. 114 pp. F. Beck, Vienna.

FALCON-LANG, H.J. 2003. Late Carboniferous tropical dryland vegetation in an alluvial-plain setting, Joggins, Nova Scotia, Canada. Palaios 18, 197-211.

DOI 10.1669/0883-1351(2003)018<0197:LCTDVI >2.0.CO;2

Fritz, A., Boersma, M. \& Krainer, K. 1990. Steinkohlenzeitliche Pflanzenfossilien aus Kärnten. Carinthia II 49, 1-189.

FritZ, K. \& Krainer, K. 2006. Vegetationsgeschichtliche und florenstratigraphische Untersuchungen im Oberkarbon und Unterperm der Ost- und Südalpen (Teil 1). Carinthia II 196/116, 93-120.

Fritz, K. \& Krainer, K. 2007. Vegetationsgeschichtliche und florenstratigraphische Untersuchungen im Oberkarbon und Unterperm der Ost- und Südalpen (Teil 1). Carinthia II 197/117, 91-148.

Gastaldo, R.A., DiMichele, W.A. \& Pfefferkorn, H.W. 1996. Out of the Icehouse into the Greenhouse: a Late Paleozoic ana$\log$ for modern global vegetational change. GSA Today 6, 1-7.

GöPPERT, H. 1836. Systema filicum fossilium. 486 pp. E. Weber, Breslau \& Bonn.

GöPPERT, H. 1841. Die Gattungen der fossilen Pflanzen vergleichen mit denen der Jetztwelt und durch Abbildungen erläutert. Band 1-2.36 pp. Henry and Cohen, Bonn.

Grand'Eury, M. 1877. Flore carbonifère du Departement de Loire et du centre de la France. Mémoires Présentés par Divers Savants à l'Académie des Sciences 24, 1-624.

GutbIER, A. von 1837. Über die gegenseitige sehr gesonderte Lagerung and die gänzlich voneinander abweichenden Pflanzenabdrücke des Rotliegend und der Kohlenformation der Gegend von Zwickau, 435-436. Isis von Oken. Dresden.

Gutbier, A. von 1849. Die Versteinerungen des Rothliegenden Sachsen, 1-32. In Geinitz, H.B. \& von GutBier, A. Die Vertseinerungen des Zechsteingebirges und Rothliegenden 
oder des permichen Systems in Sachsen. II. Arnoldische Buchandlung, Dresden \& Leipzig.

HAMER, J.J. \& Rothwell, G.W. 1988. The vegetative structure of Medullosa endocentrica (Pteridospermopsida). Canadian Journal of Botany 66, 375-387. DOI 10.1139/b88-060

Heckel, P.H. \& Clayton, G. 2006. The Carboniferous System. Use of the new official names for the subsystems, series and stages. Geologica Acta 4, 403-407.

Hemmer, A. 1920. Die fossile Flora der Oberen Ottweiler Schichten des Saarbeckens. Geognostische Jahresheft 31/32, 263-298.

Hilton, J. \& Cleal, C.J. 2007. The relationship between Euramerican and Cathaysian tropical floras in the Late Palaeozoic: palaeobiogeographical and palaeogeographical implications. Earth-Science Reviews 85, 85-116.

DOI 10.1016/j.earscirev.2007.07.003

Hoffmann, F. 1826. Untersuchungen über die Pflanzen-Reste des Kohlengebirges von Ibbenbühren und von Piesberg bei Osnabrück. Archiv für Bergbau und Hüttenwesen 13, 266-282.

Ivanović, A., SAKač, K., Marković, S., Sokač, B., ŠušnJar, M., NikLER, L. \& ŠuŠnJARA, A. 1973. Osnovna geološka karta SFRJ 1:100000, List Obrovac L33-140. Geološki zavod, Zagreb \& Savezni geološki zavod, Beograd.

Ivanović, A., Sakač, K., Sokač, B. \& Vrsalović-Carević, I. 1976. Osnovna geološka karta SFRJ 1:100000, Tumač za list Obrovac L33-140. 61 pp. Geološki zavod, Zagreb \& Savezni geološki zavod, Beograd.

JARZEMBOwSKI, E.A. 2012. The oldest plant-insect interaction in Croatia: Carboniferous evidence. Geologia Croatica 65, 387-392.

Jongmans, W.J. 1960. Die Karbonflora der Schweiz. Mit einem Beitrag von Ritter, E: Die Karbon-Vorkommen der Schweiz. Beiträge Geologische Karte Schweiz, N.F. 108, 1-95.

Kidston, R. \& Jongmans, W.J. 1917. Calamites of western Europe. Mededelingen Rijksopsporing Delfstoffen 7, 1-207.

KoCHANSKY-DEVIDÉ, V. 1955. Karbonske i permske fuzulinidne foraminifere Velebita i Like. Opći dio i karbon. Rad Jugoslavenskke akademije znanosti i umjetnosti 305, 5-62.

Kochansky-Devidé, V. 1970. Die Kalkalgen des Karbons vom Velebit-Gebirge (Moskovien und Kassimovien). Palaeontologia Jugoslavica 10, 5-32.

Lesquereux, L. 1854. New species of fossil plants from the Anthracite and Bituminous Coal-Fields of Pennsylvania, collected and described by Leo Lesquereux. Boston Journal of Natural History 6, 409-431.

Lesquereux, L. 1858. Fossil plants of the coal strata of Pennsylvania, 835-884. In Rogers, H.D. (ed.) Geology of Pennsylvania. Blackwood, Edinburgh \& Lippincott PA.

Lesquereux, L. 1880. Description of the Coal Flora of the Carboniferous in Pennsylvania and throughout the United States (1-2), 1-694. Geological Survey of Pennsylvania, Harrisburg PA (Second Report of Progress).

Lesquereux, L. 1884. Description of the Coal Flora of the Carboniferous in Pennsylvania and throughout the United States (3), 695-977. Geological Survey of Pennsylvania, Harrisburg PA (Second Report of Progress).

LinK, J.H.F. 1833. Hortus regius botanicus berolinensis 2. 376 pp. G. Reimer, Berlin.
McCann, T., Skompski, S., Poty, E., Dusar, M., VozÁrová, A., Schneider, J., Wetzel, A., Krainer, K., Kornpihl, K., SchäFer, A., Krings, M., Opluštil, S. \& TAit, J. 2008. Carboniferous, 411-529. In McCANN, T. (ed.) The geology of Central Europe. Vol. 1, Precambrian and Palaeozoic. The Geological Society, London.

Merino-Tomé, O., Bahamonde, J.R., Samankassou, E. \& Villa, E. 2009. The influence of terrestrial run off on marine biotic communities: An example from a thrust-top carbonate ramp (Upper Pennsylvanian foreland basin, Picos de Europa, NW Spain). Palaeogeography, Palaeoclimatology, Palaeoecology 278, 1-23. DOI 10.1016/j.palaeo.2009.04.002

MeYen, S.V. 1978. An attempt at a radical improvement of suprageneric taxonomy of fossil plants. Phyta 1, 76-86.

NĚMEJC, F. 1936. Contribution to the knowledge of the Carboniferous flora of the coal measures at the north-eastern foot of the Velebit mountains (Yougoslavia). Bulletin International de l'Academie des Sciences de Bohême 1936, 1-16.

NĚMEJC, F. 1937. The sphenopterides stated in the Permocarboniferous of Central Bohemia (A preliminary report. II. part). Věstník Královské České společnosti nauk 2, 1-14.

NovÁK, F.F. 1961. Vyšši rostliny. Tracheophyta. 941 pp. Nakladatelství Československé akademie věd, Prague.

NoviK, E.O. 1952. Kamennougol'naya flora evropeiskoi chasti SSSR. 468 pp. Akademiya nauk SSSR, Moscow.

PEŠEK, J. 1994. Carboniferous of central and western Bohemia (Czech Republic). 60 pp. Czech Geological Survey, Prague.

Potonié, H. 1900. Cycadofilices und sonstige Mittelgruppen zwischen Filicales und höheren Gruppen, 780-798. In Engler, A. \& Prantl, K. (eds) Die natürlichen Pflanzenfamilien. Engelmann, Leipzig.

RAGOT, L. 1955. Contribution à l'étude des formes carbonifères du genre Alethopteris. 76 pp. Unpublished thesis, Faculty of Sciences, University of Paris.

Remy, W., Andreas, D. \& Kampe, A. 1963. Beiträge zur Kenntnis des Stephanien im Saaletrog. Jahrbuch des Staatlichen Museums für Mineralogie und Geologie zu Dresden 1963, 115-146.

Renault, B. \& ZeILleR, R. 1888-1890. Études sur le terrain houiller de Commentry. Livre deuxiéme. Flore fossile. $746 \mathrm{pp}$. Société de l'Industrie Minérale, St-Étienne.

Ronchi, A., Kustatscher, E., Pittau, P. \& Santi, G. 2012. Pennsylvanian floras from Italy: an overview of the main sites and historical collections. Geologia Croatica 65/3, 299-322.

Rothwell, G.W. 1981. The Callistophytales (Pteridospermopsida): reproductively sophisticated Paleozoic gymnosperms. Review of Palaeobotany and Palynology 32, 103-121. DOI 10.1016/0034-6667(81)90076-2

SALOPEK, M. 1942. O gornjem paleozoiku Velebita u okolici Brušana i Baških Oštarija. Rad Hrvatska akademija znanosti i umjetnosti 274, 218-272.

SALOPEK, M. 1948. O gornjem paleozoiku sjeveroistočnog podnožja Velebita i Like. Prirodoslovna istraživanja, Jugoslavenska akademija znanosti i umjetnosti 24, 1-75.

SCHIMPER, W.P. 1879. Handbuch der Palceontologie. II Band. I Lieferung. 232 pp. Oldenbourg, Munich.

SCHLOtнeiм, E.F. von 1804. Beschreibung merkürdiger Kräuter-Abdrücke und Pflanzen-Versteinerungen. Ein Beitrag zur Flora der Vorwelt. 68 pp. Becker'schen Buchhandlung, Gotha. 
Schlotheim, E.F. von 1820. Die Petrefactenkunde auf ihrem jetzigen Standpunkte durch die Beschreibung seiner Sammlung versteinerter und fossiler Überreste des Thier- und Pflanzenreichs der Vorwelt erläutert. 437 pp. Becker'schen Buchhandlung, Gotha.

SCHLOtheim, E.F. von 1832. Merkwürdige Versteinerungen aus der Petrefactensammlung des verstorbenen wirklichen Geh. Raths Freiherrn v. Schlotheim. Heft 1. 40 pp. Becker'schen Buchhandlung, Gotha.

ScotT, D.H. 1909. Studies in fossil botany, $2^{\text {nd }}$ edition. $552 \mathrm{pp}$. A. \& C. Black, London. DOI 10.5962/bhl.title.57419

ShCHEGolev, A.K. 1975. Die Entwicklung der Pflanzenbedeckung im Süden des Europäischen Teils der UdSSR, vom Ende des Mittelkarbons bis zum Perm. Umfang und Gliederung des oberen Karbons (Stefan). Compte rendu $7 e$ Congrès International de Stratigraphie et de Géologie du Carbonifère (Krefeld, 1971) 4, 275-280.

SHCHEGOLEv, A.K. 1979. Verkhnii karbon severnogo Kavkaza $v$ zelenchuk-teberdinskom mezhdurech'e. 194 pp. Akademiya nauk Ukrainskoi SSR, Institut geologicheskikh nauk, Kiev.

ShCHEGolev, A.K. 1991. Palaunovidnie i klinolisti pozdnego karbona. 125 pp. Akademiya nauk Ukrainskoi SSR, Institut geologicheskikh nauk, Kiev.

Simson-Scharold, E. 1934. Zur Kenntnis der Carbonflora des Saargebietes. Palaeontographica, Abteilung B 79, 1-66.

ŠImưNeK, Z. \& MARTíneK, K. 2009. A study of Late Carboniferous and Early Permian plant assemblages from the Boskovice Basin, Czech Republic. Review of Palaeobotany and Palynology 155, 275-307. DOI 10.1016/j.revpalbo.2008.05.006

SoKač, B., Bahun, S., Velić, I. \& Galović, I. 1976a. Osnovna geološka karta SFRJ 1: 100 000. Tumač za list Otočac L 33-115. 44 pp. Geološki zavod, Zagreb, Savezni geološki zavod, Beograd.

Sokač, B., Nikler, L., Velić, I. \& Mamužić, P. 1974. Osnovna geološka karta SFRJ 1: 100 000. List Gospić L 33-127. Geološki zavod, Zagreb, Savezni geološki zavod, Beograd.

SOKAČ, B., ŠĆAVNiČAR, B. \& Velić, I. 1976b. Osnovna geološka karta SFRJ 1: 100 000. Tumač za list Gospić L 33-127. 64 pp. Geološki zavod, Zagreb \& Savezni geološki zavod, Beograd.

Sokač, B., Šušnjar, M., Bukovac, J. \& Bahun, S. 1976c. Osnovna geološka karta SFRJ 1: 100 000. Tumač za list Udbina L 33-128. 64 pp. Geološki zavod, Zagreb \& Savezni geološki zavod, Beograd.

SREMAC, J. 2012. Influence of terrestrial sedimentation in Pennsylvanian rocks of Croatia. Geologia Croatica 65/3, 273-282.

STERNBERG, K.M. vON 1820-1821. Versuch einer geognostischbotanischen Darstellung der Flora der Vorwelt 1(1,2). Part 1 (1820), 24 pp., Part 2 (1821), 33 pp. F. Fleischer, Leipzig.

STERNBERG, K.M. vON 1825. Versuch einer geognostischbotanischen Darstellung der Flora der Vorwelt 1(4, Tentamen). $48+$ xlii pp. E. Brenck's Wittwe, Regensburg.

Sterzel, J.T. 1881. Paläontologischer Charakter der oberen Steinkohlenformation und des Rotliegenden im erzgebirgischen Becken. Bericht der Naturwissenschaftlichen Gesellschaft zu Chemnitz 7, 155-270.

STIDD, B.M. \& HaLl, J.W. 1970. The natural affinity of the Carboniferous seed Callospermarion. American Journal of Botany $57,827-836$. DOI $10.2307 / 2441340$
Šušnjar, M., Sokač, B., Bahun, S., Bukovac, J., Nikler, J. \& Ivanović, A. 1973. Osnovna geološka karta SFRJ 1: 100000. List Udbina L 33-128. Geološki zavod, Zagreb, Savezni geološki zavod, Beograd.

Thomas, B.A. 1970. Epidermal studies in the interpretation of Lepidodendron species. Palaeontology 13, 145-173.

Thomas, B.A. \& Brack-Hanes, S.D. 1984. A new approach to family groupings in the lycophytes. Taxon 33, 247-255. DOI 10.2307/1221165

Thomas, B.A. \& Meyen, S.V. 1984. A system of form-genera for the Upper Palaeozoic lepidophyte stems represented by compression-impression material. Review of Palaeobotany and Palynology 41, 273-281. DOI 10.1016/0034-6667(84)90049-6

Velić, I. \& Vlahović, I. 2009. Tumač geološke karte Hrvatske 1:300.000. 141 pp. Geološki zavod, Zagreb.

VETTER, P. 1968. Géologie et paléontologie des basins houillers de Decazeville, de Figeac et du Détroit de Rodez. II. Étude paléontologique. $173 \mathrm{pp}$. Thesis for the degree of Docteur és Sciences Naturelles, University of Toulouse, Toulouse.

Vetter, P. 1986. Les formations limniques du Carbonifère supérieur et de l'Autunien en France. Mémoires de la Société géologique de France, N.S. 149, 7-14.

WAgNer, R.H. 1959a. Pecopteris pseudobucklandi Andrae and its generical affinities. Mededelingen van de Geologische Stichting, New Series 12, 25-30.

WAGNER, R.H. 1959b. Some Stephanian pecopterids from NW. Spain. Mededelingen van de Geologische Stichting, New Series $12,5-23$.

WAGNER, R.H. 1964. Stephanian floras in NW Spain, with special reference to the Westphalian D - Stephanian A boundary. Compte rendu 5 e Congrès International de Stratigraphie et de Géologie du Carbonifère (Paris, 1963) 1, 835-851.

WagneR, R.H. 1965. Stephanian B flora from the CiñeraMatallana Coalfield (León) and neighbouring outliers. III. Callipteridium and Alethopteris. Notas y Communicaciones del Instituto Geológico y Minero de España 78, 5-70.

WAGNER, R.H. 1968. Upper Westphalian and Stephanian species of Alethopteris from Europe, Asia Minor and North America. Mededelingen van de Rijks Geologische Dienst, Serie C III-1 6, 1-188.

WAGNER, R.H. 1984. Megafloral zones of the Carboniferous. Compte rendu 9e Congrès International de Stratigraphie et de Géologie du Carbonifère (Washington, 1979) 2, 109-134.

WAGNER, R.H. 1998. Consideraciones sobre los pisos de la Serie Estefaniense. Monografías Academia de Ciencias de Zaragoza 13, 9-19.

WAgner, R.H. \& Alvarez-VÁzQuez, C. 2010a. The Carboniferous floras of the Iberian Peninsula: a synthesis with geological connotations. Review of Palaeobotany and Palynology 162, 239-324. DOI 10.1016/j.revpalbo.2010.06.005

Wagner, R.H. \& Alvarez-VÁzquez, C. 2010b. A redescription of the Stephanian species Callipteridium virginianum (Fontaine \& White, 1880) comb. nov. and Alethopteris leonensis Wagner, 1964. Scripta Geologica, Special Issue 7, 93-139.

WAgner, R.H. \& CAStro Martínez, P. 1998. Neuropteris obtusa, a rare but widespread Late Carboniferous pteridosperm. Palaeontology 41, 1-22. 
Wagner, R.H., Villegas, F.J. \& Fonolla, F. 1969. Description of the Lower Cantabrian stratotype near Tejerina (León, NW. Spain). Compte rendu 6e Congrès International de Stratigraphie et de Géologie du Carbonifère (Sheffield, 1967) 1, $115-138$.

WeIss, C.E. 1869. Fossile Flora der jüngsten Steinkohlenformation und des Rothliegenden im Saar-Rhein-Gebiete. Band I. 100 pp. A. Henry, Bonn.

WEISS, [C.]E. 1870. Studien über Odontopteriden. Zeitschrift der Deutschen Geologischen Gesellschaft 22, 853-888.

WENDEL, R. 1980. Callipteridium pteridium (Schlotheim) Zeiller im Typusgebiet des Saaletrogs. Schriftenreihe für geologische Wissenschaften 16, 107-169.

ZALESSKY, M.D. 1904. Végétaux fossils du terrain carbonifère du Bassin du Donetz. I, Lycopodiales. Trudy Geologicheskii komitet, N. S. 13, 1-126.

ZENKER, F.C. 1833. Beschreibung von Galium sphenophylloides, Zenk. Neues Jahrbuch für Mineralogie, Geologie und Petrefaktenkunde 1833, 398-400.

ZoDRow, E.L. 1990. Revision and emendation of Pecopteris arborescens group, Permo-Carboniferous. Palaeontographica, Abteilung B 217, 1-49.
Zodrow, E.L. \& Cleal, C.J. 1998. Revision of the pteridosperm foliage Alethopteris and Lonchopteridium (Upper Carboniferous), Sydney Coalfield, Nova Scotia, Canada. Palaeontographica, Abteilung B 247, 65-122.

Zodrow, E.L., D’Angelo, J.A., Helleur, R. \& ŠIMỦNeK, Z. 2012. Functional groups and common pyrolysate products of Odontopteris cantabrica (index fossil for the Cantabrian Substage, Carboniferous). International Journal of Coal Geology 100, 40-50. DOI 10.1016/j.coal.2012.06.002

Zodrow, E.L., D’Angelo, J.A., Mastalerz, M. \& Keefe, D. 2009. Compression-cuticle relationship of seed ferns: insights from liquid-solid FTIR (Late Palaeozoic-Early Mesozoic, Canada-Spain-Argentina). International Journal of Coal Geology 79, 61-73. DOI 10.1016/j.coal.2009.06.001

Zodrow, E.L. \& Mastalerz, M. 2009. A proposed origin for fossilized Pennsylvanian plant cuticles by pyrite oxidation (Sydney Coalfield, Nova Scotia, Canada). Bulletin of Geosciences 84, 227-240. DOI 10.3140/bull.geosci.1094

Zodrow, E.L., Šimưnek, Z., Cleal, C.J., BeK, J. \& PšEničKa, J. 2006. Taxonomic revision of the Palaeozoic marattialean fern Acitheca. Review of Palaeobotany and Palynology 138, 239-280. DOI 10.1016/j.revpalbo.2006.01.007 